\title{
From Pawn Shops to Banks: The Impact of Formal Credit on Informal Households
}

\author{
Claudia Ruiz* \\ World Bank
}

October 2011

\begin{abstract}
This paper examines the effects of expanding access to credit on the decisions and welfare of households. I focus on the entry of Banco Azteca, the first bank in Mexico targeting households from the informal sector. Panel data suggests that informal households in municipalities with Banco Azteca experienced several changes in their saving, credit and consumption patterns. In order to estimate the impact of Azteca's entry, I develop a dynamic model of household choices in which the bank is endogenously selecting the municipalities for branch openings. I find that in municipalities in which the bank entered, households were better able to smooth their consumption even though the overall proportion of households who save went down by $5.8 \%$. These results suggest that the use of savings as a buffer on income fluctuations declines once formal credit is available. What is more, these effects vary across households with the poorest ones having the highest decline in saving rates. The model is also used to evaluate the proposed legislation to cap interest rates levied by formal credit institutions. Simulations suggest that if the Mexican government were to cap the interest rate of Azteca at the rate for traditional banks, Azteca would stop operating in the poorest and least populated municipalities.
\end{abstract}

\footnotetext{
*clauruiz@ucla.edu - I would like to thank Sandra Black, Moshe Buchinsky, Maria Casanova, Dora Costa, Pascaline Dupas, Fred Finan, Ahu Gemici, Adriana Lleras-Muney, Kathleen McGarry, Alvaro Mezza, Bernardo Morais, Leah Platt Boustan and Hernan Winkler for very helpful discussions and comments. I am extremely grateful to my advisor Maurizio Mazzocco for his invaluable suggestions and guidance. All errors are my own. Please refer to this site for the most recent version of the paper: https://sites.google.com/site/claudiaruizortega.
} 


\section{Introduction}

Formal credit institutions are reluctant to lend to households without credit history and verifiable steady employment. These two characteristics are inherent to people employed in the informal sector, which includes any economic activity that is not taxed or monitored by the government. This is a concern in developing countries, where the fraction of people working in an informal occupation is considerably large. In 2002, for example, 55\% of Mexicans belonged to the informal sector. This does not imply that usage of credit among these people is low. On the contrary, households that cannot obtain credit from banks are very active borrowers with alternative suppliers. They rely heavily on loans from relatives and friends, and on more expensive credit suppliers such as pawn shops and moneylenders. According to the Mexican Family Life Survey 2002, of all informal households in $2002,3.7 \%$ of them used pawn shops or moneylenders' credit and $13.8 \%$ obtained loans from friends or relatives.

The goal of this paper is to analyze the effects of expanding access to credit on households' decisions and welfare. To do this, I examine the opening of Banco Azteca, the first bank in Mexico that targeted households employed in the informal sector. Using panel data at the household level, I first analyze households' saving and consumption patterns before and after the entrance of this bank. I then develop and estimate a dynamic model of household choices in which Banco Azteca selects the municipalities for branch openings. This is, to my knowledge, the first structural attempt at jointly modeling household choices and the location decisions of banks to measure the impact of access to credit.

There are several advantages of using this structural approach. First, since the entry of Azteca in a given municipality is unlikely to be exogenous, estimating its impact on households' welfare is difficult. The model deals with this issue by endogenizing the location decisions of the bank. Second, the estimated model allows to quantify the impact of the expansion of credit caused by the entrance of Banco Azteca. Third, the model can be used to evaluate alternative policies aimed at extending access to credit. In this paper, I evaluate the proposed regulation of capping interest rates of formal credit institutions.

On October 2002, Banco Azteca opened more than 800 branches across the country. At the time, these branches accounted for 15\% of the supply of bank branches in Mexico. This new bank eliminated the proof of income requirement and hence allowed all Mexicans from the informal sector to obtain bank credit for the first time. In terms of costs for borrowers, Azteca's annual percentage rate 
(APR) has been significantly higher than traditional banks': its APR in 2005 was 130\% compared to $40 \%$ of regular banks. Nevertheless, it is lower than its competitors; in this same year, pawn shops charged on average an APR of $220 \%{ }^{1}$.

Panel data suggests that households whose members were employed in the informal sector had significant changes in their saving and consumption patterns after an Azteca branch appeared in their municipalities. The households data consists of two waves that were collected in 2002 and 2005. By the time of the first wave, Banco Azteca had not opened its branches, but by 2005, Banco Azteca's presence varied across municipalities. I exploit this variation over time and across municipalities of Azteca's branches to compare household outcomes before and after the entrance of Banco Azteca. I find evidence that relative to households from municipalities where this bank did not open, informal households in Azteca municipalities were more likely to borrow from banks, less likely to obtain loans from pawnshops and less likely to save. In addition, the fraction of informal households owning durable goods increased as did the value of these goods. Moreover, in municipalities where Azteca opened, informal households were more likely to increase their consumption during bad economic times, such as unemployment or failure of the family business.

The model includes important features from the Mexican economy. To capture heterogeneity among municipalities in Mexico, the economy in this model consists of $M$ municipalities that differ in population size, income distribution and presence of credit suppliers. While every household has an offer from the informal sector every period, only a fraction of them obtains formal-sector offers. As in the Mexican credit market, households can borrow from traditional banks, pawn shops, Banco Azteca and friends or relatives. In the model, Banco Azteca is a for-profit institution that selects the municipalities for branch openings. The bank locates in municipalities where its expected profits are high enough to cover its operating costs. In this economy, credit suppliers differ in their costs, availability and requirements for clients. The APR of each institution is set to the average rate observed from the data, being pawn shops the most expensive and friends the less costly. When borrowing from banks, Azteca and pawn shops, households need to own collateral to back up their loans. Durable goods serve as households' collateral and in case of default, the credit institution retains it. Importantly, traditional banks have the additional constraint of requiring their clients to belong to the formal sector. Given all these constraints, households maximize their expected lifetime utility by each period making several choices. First, those who obtain job offers from both sectors, must choose

\footnotetext{
${ }^{1}$ Information on the APR of different institutions was obtained from the National Committee for the Defense of Users of Financial Institutions (CONDUSEF) and the Federal Bureau of Consumer Interests (PROFECO).
} 
whether to belong to the formal or the informal sector. They then decide how many durable goods to own and how much savings or debt to acquire. After choosing their savings and expenditure on the durable goods, the remaining resources at each period determine the consumption of the non durable good.

The quantitative results indicate that with the entrance of Banco Azteca, households are better able to smooth their consumption and on average accumulate more durable goods. Providing them with access to bank credit translates in lower usage of pawn shop loans and for low-income households, in lower levels of savings. Once access to formal credit is available, the fraction of households who save declines by $5.8 \%$. This suggests that savings were being used as a buffer on income fluctuations in the absence of credit. Consistent with the targeted population of Banco Azteca, informal households experience higher welfare gains. Nevertheless, even non-borrower households benefit from Azteca's entry since their potential ability to borrow in the future increased.

Since the model includes the entry and exit decisions of this bank, it is well suited to evaluate a regulation that would cap the interest rate that formal credit institutions charge. Several policy makers in Mexico have suggested this measure in order to make loans more affordable to people. However, as capping the interest rate would alter Azteca's expected profits, this policy could have the unintended consequence of forcing Azteca out of municipalities where it is no longer profitable to mantain a branch. My results suggest there would be a substantial welfare loss if the government were to cap Azteca's APR to 40\%. At the new APR, more households would obtain bank loans and the average size of these loans would be larger. However, in some municipalities households' response would not compensate for the decrease in the APR. Simulations of this model indicate that the bank would exit from $14 \%$ of the currently covered municipalities. The likelihood of losing a branch is higher in municipalities with lower percapita income and less population size.

Broadly, my results fit into the literature that analyzes the impacts of expanding financial services to poor households. Burgess and Pande (2005) exploit the implementation of a bank branch licensing rule in India to estimate the effect of rural bank branches on poverty. They find that the expansion of branches significantly decreased poverty in rural areas. In the same context as this paper, Bruhn and Love (2009) analyze the effects that the entrance of Banco Azteca had on business and employment outcomes. Their evidence suggests that relative to municipalities without Azteca, in municipalities where Azteca initially entered, workers were more likely to open informal business and benefited from higher income levels.

In addition to these papers, there is a growing literature that has studied the effects of expand- 
ing access to credit to low-income households in more quasi-experimental or randomized settings. Kaboski and Townsend (2008) develop and estimate a structural model to predict and evaluate the impact of the Thai Million Baht Village Fund program, a major microcredit initiative that was rapidly implemented in one year and gave the same amount of funds to all villages, regardless of their size. They find sizeable effects on consumption as a result of the credit program. Banerjee et al. (2009) exploit the random expansion of a microfinance institution in urban India, and find heterogeneous effects on income and consumption of households. Under a randomized experiment, Karlan and Zinman (2008) examine the impact of obtaining consumer credit at $200 \%$ APR in urban Philippines. They find that borrowers significantly benefited on their job retention, income and other consumption outcomes. My paper contributes to this literature by providing one of the first attempts to estimate a model of household decisions that considers the endogenous location of credit providers.

This paper is organized as follows. Section 2 describes the data set used and the patterns of households over time in municipalities with and without Azteca branches. Sections 3, 4 and 5 present the model, the model solution and its estimation. Section 6 presents the estimation results and the model fit assessment. The robustness of the model and the quantification of Azteca's impact are examined in Sections 7 and 8. The policy experiment is discussed and evaluated in Section 9. Finally, Section 10 concludes.

\section{Data and Empirical Findings}

This section describes the data used in this paper. It also provides empirical evidence that suggests that the saving and consumption patterns of informal households changed substantially in municipalities where Banco Azteca opened.

The data for households comes from the Mexican Family Life Survey (MxFLS), waves 2002 and 2005. At the time of the first wave, Banco Azteca had not opened its branches, but by 2005, its presence varied across municipalities. This panel survey is representative at the national level and importantly, it provides detailed information about Mexicans' credit and savings habits. I focus the analysis on households that were surveyed in both waves and in which the head is between 18 and 65 years old. The final sample from the baseline survey consists of 5,639 households in 136 Mexican municipalities. To examine the characteristics of municipalities in which Banco Azteca opened its branches, I include information from the 2000 Mexican Census and the Human Development Index 
of Mexican Municipalities ${ }^{2}$. The household data was merged with a panel dataset from the National Banking and Securities Commission (CNBV), which contains the location and year of opening of all bank branches across Mexican municipalities.

I begin by examining which factors are determining the entry of Banco Azteca into a municipality. Population size, per capita income and presence of traditional bank branches seem to be strongly correlated with the location of the bank's branches. In table 1, I classify municipalities according to the presence of Banco Azteca and for each category, I report the distribution of population size and per capita income. The table also includes the fraction of municipalities with traditional bank branches and the number of municipalities in each category. Most municipalities from this sample either had an Azteca branch from 2002 to 2005 (63 of them) or never had one (67 of them). According to the data, municipalities where Azteca decides to locate its branches are more populated, have higher percapita income and are also more likely to have traditional bank branches than the average municipality in Mexico. On the contrary, municipalities where Azteca never entered have smaller populations, lower per capita income and less penetration of traditional banks than the average municipality. Although highly correlated, these variables do not explain completely the location decisions of the bank. The last column of the table shows that Azteca stayed out of some municipalities with similar population and per capita income than others where Azteca entered. It could be for example, that Azteca faced more competition in those municipalities and it was not profitable to enter there. This however, is information that remains unobserved in the data.

I now present several saving and consumption patterns over time of households from municipalities with and without Azteca.

I now classify municipalities present several patterns from the household data.

I now present several patterns from the household data.

Specifically, empirical evidence that examines whether households behaved differently in municipalities where Banco Azteca opened. The outcomes to analyze are the following.

Table 2 presents descriptive statistics on household data classified by the presence of Azteca across municipalities. Column 1 reports information on households from municipalities that had an Azteca branch in 2005. Information of all other households is shown in column 2. In the baseline year,

\footnotetext{
${ }^{2}$ The Human Development Index of Mexican Municipalities can be downloaded from: http:/ /www.undp.org.mx/desarrollohumano/disco/index.html.
} 
there are 3,483 households in municipalities where this bank later appeared and 2,156 households in municipalities where it did not. Since Banco Azteca targets clients employed in the informal sector, it is important to classify households as formal and informal. I consider a household formal if any of its nuclear members- the household head, the spouse and the children- has a job that provides Social Security benefits. Otherwise, it is considered informal. The share of households that belong to the formal sector was higher in Azteca municipalities. To understand whether households are better able to deal with economic shocks in the presence of formal credit, I focus on the sample of households that experienced a negative economic shock, defined as the unemployment or failure of business of the household head. $6.4 \%$ and $3.6 \%$ of households in Azteca and non-Azteca municipalities report having a bad economic shock in 2002. This share increased to $7.9 \%$ and $5.5 \%$ in 2005 . The last descriptive statistics report the share of households that experienced a bad shock conditional on their sector.

Table 2 presents descriptive statistics on the households data classified according to the presence of Azteca across municipalities. Column 1 reports information of households from municipalities that had an Azteca branch in 2005. Information of all other households is shown in column 2. The baseline year consists of 3,483 households in municipalities where this bank later appeared and 2,156 households in municipalities where Azteca did not open. Since Banco Azteca targets clients employed in the informal sector, it is important to classify households into formal and informal. I consider a household as formal if any of its nuclear members- household head, spouse and sons or daughters- has a job that provides Social Security benefits. Otherwise, the household is considered informal. The share of households that belong to the formal sector was higher in Azteca municipalities than in non-Azteca in the baseline year, 0.238 and 0.131, and stayed higher in 2005, 0.229 and 0.125 respectively. To understand whether households are better able to deal with economic shocks in the presence of formal credit, I focus on the sample of households that experienced a bad economic shock, defined as the unemployment or failure of business of the household head. $6.4 \%$ and $3.6 \%$ of households in Azteca and non-Azteca municipalities report having a bad economic shock in 2002. This share increased to $7.9 \%$ and $5.5 \%$ in 2005. The last descriptive statistics report the share of households that experienced a bad shock conditional on their sector.

I now examine whether changes on households' saving and consumption patterns over time were correlated to the opening of an Azteca branch. To do so, I exploit the variation over time and across municipalities of Azteca's branches to compute difference-in-difference (DID) estimates. The DID 
estimates compare the difference in households' means before and after Azteca's opening between Azteca and non-Azteca municipalities. Azteca municipalities consist of municipalities that had an Azteca branch by 2005 while non-Azteca are all other municipalities. The econometric specification to compute the DID estimate consists of:

$$
y_{h, m, t}=\alpha_{0}+\alpha_{1} \text { Azteca }_{m}+\alpha_{2} \text { year }_{t}+\alpha_{3} \text { Aztyear }_{m, t}+\alpha_{4} X_{h, m, t}+\alpha_{5} Z_{h}+\varepsilon_{h, m, t}
$$

where $h, m, t$ denote households, municipalities and whether the year is 2002 or 2005. $X_{h, m, t}$ is a vector of controls for household demographics and municipality characteristics that are: education of the household head, if household is in a rural village, size of municipality and presence of traditional bank branches or other government credit institutions. $Z_{h}$ is a set of household fixed effects that control for all the unobserved variation of households that is fixed over time, such as household preferences towards risk aversion. The DID estimator is captured by $\alpha_{3}$, the coefficient of the indi-

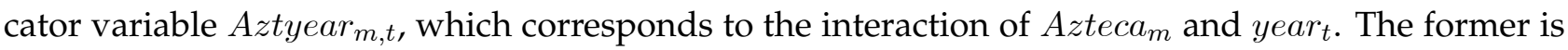
a dummy that equals one if the municipality had an Azteca by the time the second wave of MxFLS was collected. The latter equals 0 if the year is 2002 and 1 otherwise.

Table 3 presents the saving patterns of households over time. The first variable reflects households' knowledge about bank loans. This is an indicator variable that equals one if a household knows it can borrow from banks and zero otherwise. As seen from the table, the fraction of households that knew they can use bank loans increased from 2002 to 2005 in both Azteca and non-Azteca municipalities. However, the DID estimator indicates that in municipalities with Azteca branches, the probability that households knew they can obtain bank loans increased more than in municipalities with no Azteca. The DID estimator (0.0895) implies that after Banco Azteca opened, relative to municipalities with no branch of this bank, the probability that households in Azteca municipalities knew they can borrow from banks was $60 \%$ higher once this bank opened. This outcome is important since it measures households potential ability to borrow in the future from banks, which could be altering their consumption and saving decisions in the present. The next variable examined is the probability that households obtain bank loans. According to the DID estimator, households from municipalities where Azteca opened were twice more likely to obtain bank loans $\left(\alpha_{3}=0.0106\right)$. In addition, the average loan size of households that borrowed from banks increased in $\$ 371$ Mexican pesos. These results suggest that once Banco Azteca operated in a municipality, households' ability to borrow from banks increased. To explore if households from municipalities where Banco Azteca opened reduced their usage of more expensive credit suppliers, I present the means over time and 
the DID estimates of the probability that households borrowed from pawn shops. The results suggest that the likelihood that a household borrowed from pawn shops dropped significantly by 0.0085 points in municipalities in which Azteca located its branches relative to municipalities where Azteca did not enter, which is a sizeable decline of $39 \%$. According to the buffer stock savings model, in the presence of credit constraints, households hold a buffer stock of savings to counter the effects of future income shocks. To examine whether there is evidence of this behavior in the data, I estimate DID regressions on two savings variables: the proportion of households who save, and conditional on saving, the amount saved by households. The results suggest that by 2005 in Azteca municipalities, the proportion of households saving significantly decreased in 0.0403 , which represents a drop of $11 \%$ from the 2002 mean. These patterns still hold when looking at the average savings of those households saving. By 2005, households from municipalities in which Azteca operated branches held on average less savings (a decline of \$5,316 Mexican pesos) relative to households in municipalities without Azteca. These results are consistent with the implications of the buffer stock model.

Since in municipalities with an Azteca branch households are more likely to use formal credit and less likely to save, we might expect them to increase their consumption or investment expenditures. From their stated reasons for borrowing, 35\% of households reported using the credit to purchase or repair durable goods and 50\% used the money for consumption reasons, most of them due to a poor economic situation. Only $8.5 \%$ of the households stated they used the credit to start a new business or to invest in one.

To examine whether households were accumulating more durable goods and of better quality once Azteca opened branches in their municipalities, I compare means over time and compute DID estimates on 6 different outcomes: the proportion of households that own electronic appliances (radio, TV set, VCR, computer, etc.) and the reported value of these goods; the proportion of households that own furniture and large appliances (such as washing and dryer machine, stove, refrigerator) and their reported value; and the fraction of households owning other appliances (blender, iron, microwave, etc.), and their value. Table 4 shows the means over time and across presence of Azteca and the DID estimates. In Azteca municipalities, households were more likely to own electronic appliances $\left(\alpha_{3}=0.02\right)$, large appliances and furniture $\left(\alpha_{3}=0.022\right)$, and other appliances $\left(\alpha_{3}=0.0256\right)$. Moreover the value of these goods significantly increased in \$2,373 Mexican pesos for electronic appliances and \$2,487 Mexican pesos for furniture and large appliances.

A more common reason for households to borrow was to finance their consumption during bad economic times. In the survey, households were asked about certain events that caused economic 
losses to them and the date when these events occurred. I define a bad economic shock as the unemployment or business failure of the household head that took place during the year of the survey. To test whether households' consumption was higher in these bad times, I restrict the sample to households that experienced this event and look at their percapita expenditure. The last rows of table 4 show the results. The 2002 and 2005 means of the percapita expenditure suggest that households from Azteca municipalities were better able to increase their consumption during bad economic times after Azteca opened branches. The DID estimator with household fixed effects $\left(Z_{h}\right)$ is positive but not significant. This must be due to the lack of within-household variation as the restricted sample is less than $10 \%$. For this reason, I also include the OLS DID estimator, which suggests a positive and significant increase in percapita expenditure of $\$ 4,978.8$ Mexican pesos.

So far, I have presented suggestive evidence that the saving and consumption patterns of households from Azteca municipalities are significantly different after Banco Azteca opened, relative to the changes over time of households from non-Azteca municipalities. I now examine whether these changes were concentrated on informal households, since these households had access to formal credit for the first time with the opening of Azteca. Table 5 presents the saving patterns of the sample of informal households. Compared to informal households from non-Azteca municipalities, after the opening of Azteca informal households in Azteca municipalities were 76\% more likely to know they can borrow from banks $\left(\alpha_{3}=0.1008\right)$. Their likelihood of obtaining loans from banks more than doubled ( $\alpha_{3}=0.0137$ ) and the size of loans they obtained from banks increased substantially by $\$ 494$ Mexican pesos. Moreover, after the entrance of Azteca in their municipalities, the probability of informal households of obtaining pawnshop credit decreased in $45 \%\left(\alpha_{3}=-0.01\right)$, relative to the pre-post Azteca means of informal households without Azteca branches. In addition, the fraction of informal households who saved and the average savings of these households substantially decreased in $11 \%$ $(-0.0366)$ and $47 \%(4,736)$, respectively.

As seen in table 6, the consumption patterns of informal households changed substantially more in municipalities with an Azteca branch than in municipalities without one. In Azteca-municipalities after the opening of Banco Azteca, informal households were more likely to own electronic (0.0216) and other (0.0305) appliances. The value of their electronic appliances increased by $22.5 \%(\$ 1,588.5$ Mexican pesos), and of their furniture and large appliances by 31\% (\$2,889 Mexican pesos). Regarding evidence of consumption smoothing, I now examine percapita expenditure of informal households who reported a bad economic shock (failure of family business or unemployment of head). Again, I present the DID estimates with and without household fixed effects. As seen from the per- 
capita expenditure means, relative to informal households in non-Azteca municipalities, by 2005 informal households' percapita expenditure increased in municipalities with Azteca. The household fixed effects DID estimate is positive but not significant, probably due to the lack of within-household variation caused from restricting the sample to only households experiencing bad economic shocks. However, the OLS DID estimate that does not exploit this within-household variation, suggests that informal households in Azteca municipalities substantially increased their percapita expenditure in $34 \%$ (\$5,502 Mexican pesos).

The next two tables, 7 and 8, report the means over time and the DID estimates of the saving and consumption patterns of households whose members belong to the formal sector. Consistent with the clients that Banco Azteca targets, relative to formal households in non-Azteca municipalities, formal households from municipalities with Azteca branches did not change significantly their patterns after the opening of this bank. Altogether, the data suggests that informal households from municipalities where Azteca opened experienced significant changes in their saving and consumption patterns.

\section{Model}

I now present the dynamic model in which households interact, among other credit suppliers, with Banco Azteca. The model can be divided in two parts: the problem of the households and the problem that Banco Azteca solves.

Before describing the households' problem, it is useful to explain some features of the model. The economy in this model consists of $M$ municipalities populated by households. Consistent with the data, municipalities differ from each other in their population size $\left(P^{m}\right)$, income distribution $\left(Y^{m}\right)$ and presence of credit suppliers. While all municipalities in the model have pawnshops, only in some there are traditional banks $\left(B^{m}\right)$ and Azteca branches $\left(A_{t}^{m}\right)$. Note that the presence of Azteca branches also varies over time. Households in this economy can also borrow from friends and relatives $\left(R_{t}^{m}\right)$, but only in periods when these suppliers are available to them. In the model, $R_{t}^{m}$ corresponds to the fraction of households with access to credit from friends and relatives, which varies

over time and across municipalities. Let $f r_{t}^{h, m}$ be the realization of whether credit from friends and relatives is available to household $h$ of municipality $m$ at period $t$.

In this economy there exist two sectors to which households belong, a formal sector and an informal one. All households receive a job offer from the informal sector at every period $t$, but they only receive a formal-sector job offer with probability $f_{t}^{h}$. According to the data, more educated 
households are more likely to be in a formal occupation, and once a household belongs to the formal sector, the probability of staying in this sector is high. Hence, the model allows $f_{t}^{h}$ to depend on whether the household belonged to the formal sector in the last period and on the education of the household head, $e^{h}$. Households that have one job offer from each sector, decide in which sector to be employed. Let $y_{t}^{F, h}$ and $y_{t}^{I, h}$ be the income offered from the formal and the informal sector to household $h$ at period $t$. For both sectors, the income offered depends on the previous income of the household $\left(y_{t-1}^{h}\right)$ and the education and age of the household head $\left(e^{h}, a_{t}^{h}\right)$. These variables proved to explain accurately the two income processes in the data. In the model, the magnitude in which these variables determine the income is allowed to be different between sectors. In addition, every period each income offer is subject to an idiosyncratic shock. Let $v_{t}^{I, h}$ be the shock to the income from the informal sector and $v_{t}^{F, h}$ from the formal one. These two shocks are drawn from a different distribution, depending on the sector.

\subsection{Households' Problem}

Households have preferences over consumption goods $\left(c_{t}^{h}\right)$ and the service flow of durable goods $\left(\widetilde{D}_{t}^{h}\right)$. While consumption goods only last one period, durable goods yield utility over time, but depreciate periodically at a rate of $\delta$. Households' preferences are summarized by the utility function:

$$
u\left[c_{t}^{h}, \widetilde{D}_{t}^{h}\right]
$$

Households make several decisions in order to maximize their expected lifetime utility. Each period, households who observe an offer from the formal sector, decide whether to belong to the formal sector or not $\left(F_{t}^{h}=0,1\right)$. Once they know their sector and their labor income $\left(y_{t}^{h}\right)$, households then decide how much durable goods to have $\left(D_{t}^{h}\right)$, and how much to save or borrow $\left(s_{t}^{h}\right)$. The remaining income determines the consumption good $\left(c_{t}^{h}\right)$ at period $t$. The optimal set of decisions $\left(F_{t}^{h^{*}}, D_{t}^{h^{*}}, s_{t}^{h^{*}}\right)$ maximizes households' expected lifetime utility, defined as:

$$
E\left[\sum_{t=1}^{T} \beta^{t} u\left[c_{t}^{h}, \widetilde{D}_{t}^{h}\right]\right]
$$

subject to three constraints. First, in each period $t$ and state of nature $\omega_{t}^{h}$, expenditure on consumption goods, purchase of durable goods $\left(i_{t}^{h}\right)$ and savings must equal the available resources,

$$
c_{t}^{h}+i_{t}^{h}+s_{t}^{h}=y_{t}^{h}+\left(1-d_{t}^{c r, h}\right) \cdot\left(1+r^{c r}\right) s_{t-1}^{h},
$$


where $r^{c r}$ is the interest rate that corresponds to credit supplier $c r$ and $d_{t}^{c r, h}$ is an indicator function that equals 1 if a household defaults at $t$ to a loan $s_{t-1}^{h}$ from credit supplier $\mathrm{cr}$. In this model, households do not choose to default. Default occurs automatically when households' total resources are not enough to cover their debt.

The second constraint refers to the evolution of the durable goods. The value of the durable goods at each $t$ must equal the value of the depreciated durable goods from period $t-1$ plus any purchase made at $t$. In case of default- i.e. when $d_{t}^{c r, h}=1$, the household loses the collateral $q x_{t-1}^{h}$, where $q$ is the market price of one unit of the durable good relative to one of consumption and $x$ is the durable good that served as collateral of a loan acquired at $t-1$,

$$
q D_{t}^{h}=(1-\delta) q D_{t-1}^{h}+i_{t}^{h}-d_{t}^{c r, h} \cdot q x_{t-1}^{h},
$$

Notice from the first constraint that when the default indicator function equals 1 , the household debt disappears, but from the second constraint, the household loses the durable goods $x_{t-1}^{h}$ that were pledged as collateral.

The third constraint refers to the barriers into the credit market. When households decide to request a loan, the first credit constraint they face is the availability of credit suppliers in their municipalities. Once households know which credit suppliers are available in their municipalities, they would need to own sufficient durable goods to secure the repayment of their loans if borrowing from banks, Azteca or pawnshops. Moreover, if borrowing from Azteca or traditional banks, they need to have no default incidents in the past with them. As is the case in Mexico, where two different credit bureaus exist for these institutions, in the model, banks and Azteca do not share information with each other, therefore if a household defaulted in the past to an Azteca loan, $\left(d_{t-1}^{A, h}=1\right)$, traditional banks are not aware of it. The final restriction applies to those households requesting loans to traditional banks, who are required to be employed in the formal sector at the time of the loan request.

\subsubsection{Lending Decision Rule}

Profit-maximizing suppliers of the model, which are traditional banks, Azteca and pawn shops, accept to lend to a client if he owns the collateral required, which is determined by the size of the loan. Hence, the higher the value of the durable goods of a household, the higher the loan it can receive from these institutions. 
We might think that friends and relatives have different motives when lending. They might extend loans to guarantee that when in need, they can borrow from friends they lent in the past, or even because they care about the welfare of the loan recipient. To simplify these motives, the model assumes that whenever a household has access to loans from friends or relatives, these suppliers always lend it up to a maximum that is estimated in the model.

Banco Azteca is the only credit supplier that decides where to locate its branches. The location of the other credit suppliers is fixed over time. Additionally, the model abstracts from other decisions that credit suppliers make such as the interest rate to charge or the collateral to require. In the model, these decisions are fixed to the choices observed from the data, which are assumed to be the optimal decisions that credit suppliers made in the past under the assumption that these decisions do not change by the entrance of Azteca.

\subsection{Problem of Banco Azteca}

Banco Azteca maximizes its expected profits by deciding at every period $t$ in which municipalities to locate its branches. Azteca's expected profits are the sum of the $M$ municipalities' expected profits:

$$
E\left[\Pi_{t}\right]=\sum_{m=1}^{M} E\left[\Pi_{t}^{m}\right],
$$

where $E\left[\Pi_{t}^{m}\right]$ consists of two components. The first one corresponds to the gains that Azteca expects to receive at $t+1$ from lending to the households of municipality $m$ at $t$. The second component refers to the cost associated to the operation of the branch, $\chi$, which is a cost at the municipality level that must be paid every period that Azteca operates a branch. Let $A_{t}^{m}$ equal 1 if Azteca decides to open a branch in municipality $m$ at period $t$, and 0 otherwise. In addition, let $H$ be the number of households from $m$. If $A_{t}^{m}=1$, Azteca locates in $m$, pays $\chi$ and next period receives $E\left[\pi_{t+1}^{h, m} \mid \omega_{t}^{h}\right]$ from each of the $H$ households of $m$. Azteca's expected profits if entering $m, E\left[\Pi_{t}^{m, A_{t}^{m}=1}\right]$, would then be:

$$
E\left[\Pi_{t}^{m, A_{t}^{m}=1}\right]=\sum_{h=1}^{H} E\left[\pi_{t+1}^{h, m} \mid \omega_{t}^{h}\right]-\chi .
$$

If, on the other hand, Azteca decides not to open a branch in $m$ at period $t$, its expected profits would simply be zero,

$$
E\left[\Pi_{t}^{m, A_{t}^{m}=0}\right]=0
$$

Hence, Azteca decides to operate a branch in $m$ if the expected gains from lending to its $H$ households are high enough to cover $\chi$. We can then write $E\left[\Pi_{t}^{m}\right]$ as: 


$$
E\left[\Pi_{t}^{m}\right]=\underset{A_{t}^{m}=0,1}{\operatorname{Max}}\left\{E\left[\Pi_{t}^{m, A_{t}^{m}=0}\right], E\left[\Pi_{t}^{m, A_{t}^{m}=1}\right]\right\}
$$

Notice that to solve its problem, Azteca only needs to compute at every period $t$ the profits it expects to receive from every household at each municipality, $E\left[\pi_{t+1}^{h, m} \mid \omega_{t}^{h}\right]$. Notice also that the expected profits of a household $h$ depend on its state of nature at $t, \omega_{t}^{h}$. An important assumption of this model is that Azteca observes the state of nature of every household and knows the distribution of all the idiosyncratic shocks. With this information, Azteca solves the problem of the households and from it, obtains each household's expected profits, which are given by:

$$
\begin{array}{ll}
\text { If } s_{t}^{h^{*}}<0: & E\left[\pi_{t+1}^{h, m} \mid \omega_{t}^{h}\right]=\left(1-p_{t}^{h}\right) \cdot r^{A}\left(-s_{t}^{h^{*}}\right)+p_{t}^{h}\left(q x_{t}^{h}+s_{t}^{h^{*}}\right) \\
\text { If } s_{t}^{h^{*}} \geq 0: & E\left[\pi_{t+1}^{h, m} \mid \omega_{t}^{h}\right]=0
\end{array}
$$

where $p_{t}^{h}$ is the probability that $h$ defaults to the loan $s_{t}^{h}$. This probability is computed optimally from solving the problem of the households. As Azteca observes $\omega_{t}^{h}$ and the distribution of idiosyncratic shocks, $p_{t}^{h}$ is simply the likelihood that $h^{\prime} s$ total resources at $t+1$ are not enough to cover its debt from $t$.

\section{Model Solution}

The interaction between households and credit suppliers is as follows. At the beginning of each $t$, the idiosyncratic shocks are observed by all households and credit suppliers. These shocks consist of the fraction of households with access to credit from friends and relatives in each municipality, $R_{t}^{m}$; based on $R_{t}^{m}$, households observe whether they have access to credit from friends or relatives or not, $f r_{t}^{h}$; at the same time, households find out whether they receive an offer from the formal sector or not, $f_{t}^{h}$; and finally they observe the shocks to the formal and informal labor incomes, $v_{t}^{I, h}, v_{t}^{F, h}$. Once all these shocks are realized and observed, households who brought a debt to the period and have not enough resources to pay it back, default. These households give up the durable goods pledged as collateral to their lenders. At this stage, Azteca decides in which municipalities to open its branches.

To decide the location of its branches, Azteca computes the profits it expects to receive from every household, $E\left[\pi_{t+1}^{h, m} \mid \omega_{t}^{h}\right]$, and sums up these expected profits by municipality. Based on them, the bank opens its branches in municipalities where its expected gains cover the operation cost,

$$
A_{t}^{m}=\left\{\begin{array}{ll}
0 & \text { if } \sum_{h=1}^{H} E\left[\pi_{t}^{h, m} \mid \omega_{t}^{h}\right]<\chi \\
1 & \text { if } \sum_{h=1}^{H} E\left[\pi_{t}^{h, m} \mid \omega_{t}^{h}\right] \geq \chi
\end{array} \text { for } m=1, \ldots, M\right.
$$


Once Azteca opened its branches across municipalities, households are ready to make their decisions. The recursive problem of each household at every period $t$ can be written in the following form:

$$
\begin{gathered}
V^{h}\left(\omega_{t}^{h}, t\right)=\max _{c_{t}^{h^{*}}, s_{t}^{h^{*}}, D_{t}^{h^{*}}, F_{t}^{h^{*}}} u^{h}\left[c_{t}^{h}, \widetilde{D}_{t}^{h}\right]+\beta E\left[V^{h}\left(\omega_{t+1}^{h}, t+1\right)\right] \\
\text { s.t. } \\
c_{t}^{h}+i_{t}^{h}+s_{t}^{h}=y_{t}^{h}+\left(1-d_{t}^{c r, h}\right) \cdot\left(1+r^{c r}\right) s_{t-1}^{h}, \\
q D_{t}^{h}=(1-\delta) q D_{t-1}^{h}+i_{t}^{h}-d_{t}^{c r, h} \cdot q x_{t-1}^{h}
\end{gathered}
$$

where the set of state variables of household $h$ at period $t, \omega_{t}^{h}$, first includes households' characteristics from the previous period, that are: their level of savings, $s_{t-1}^{h}$; the amount of durable goods, $D_{t-1}^{h}$; their labor income, $y_{t-1}^{h}$; their previous employment sector, $F_{t-1}^{h}$; the credit institution for those who borrowed, $c r_{t-1}^{h}$; the default history with Azteca, $d_{t-1}^{A, h}$; the default history with traditional banks, $d_{t-1}^{B, h}$; and the education level of the household head $e^{h}$. Finally, $\omega_{t}^{h}$ also includes characteristics of the households' municipalities, that are: presence of traditional bank branches, $B^{m}$; population size, $P^{m}$; income distribution of the municipality, $Y^{m}$; and the fraction of households with access to credit from friends and relatives at $t-1, R_{t-1}^{m}$. Households compute their expected value functions using the distribution of the shocks $R_{t}^{m}, f r_{t}^{h}, f_{t}^{h}, v_{t}^{I, h}, v_{t}^{F, h}$ at period $t+1$.

I solve the model by backwards recursion, starting from the last period of life $T=75$, to the initial period $t_{0}=18$, for a given household. As it is a finite horizon problem, it is assumed that the terminal value is equal to zero- i.e. in their terminal period of life, the value functions of the households equal the utility at $T$. At periods $t<T$, the value functions of the households equal the utility at $t$ plus the expected value function of $t+1$.

Keane and Wolpin (1994) show how to recover these expected value functions, which they call the Emax function. This function is calculated for every point of the state space, any period $t$ and every possible choice set. In this model, the size of the state space was discretized and, following Keane and Wolpin (1994), the Emax functions were approximated by a parametric function of the current state variables.

\subsection{Empirical specification}

I now describe the functional form assumptions made for the following processes of the model: household production function; utility function; labor income process from the formal and informal sectors; transition of informal credit across municipalities and over time. 
Households' production function: In the model, the flow of services from durable goods $\left(\widetilde{D}_{t}^{h}\right)$ is produced by a linear household production function, in which the stock of durable goods $D_{t}^{h}$ is transformed by the productivity parameter $\eta_{1}>0$ into the flow of services enjoyed by the household at each period $t$ :

$$
\widetilde{D}_{t}^{h}=\eta_{1} D_{t}^{h}
$$

Utility: The preferences of households are assumed to have the following functional form with respect to the nondurable goods and the service flow of durable goods:

$$
U_{t}^{h}=\left(\frac{c_{t}^{h}}{1-\gamma}\right)^{1-\gamma}+\eta_{0} \widetilde{D}_{t}^{h}
$$

with $\gamma>0$ and $\eta_{0}>0$. The parameter $\gamma$ captures the intertemporal substitution of the nondurable good $c_{t}^{h}$. This parametrization implies that household $h / s$ intertemporal elasticity of substitution is $-1 / \gamma$. Note that since I assume that the flow of services of durable goods is produced by a linear household production function, I will not be able to separately identify the preference for the service flow of durable goods $\left(\eta_{0}\right)$ from the household productivity $\eta_{1}$. I will only identify their product $\left(\eta_{0} \eta_{1}\right)$

Total labor income: The total labor income offers from the formal and informal sectors are drawn from the following processes:

$$
\begin{aligned}
& y_{t, h}^{F}=\alpha_{1, F} \cdot y_{t-1}^{h}+\alpha_{2, F} \cdot e^{h}+\alpha_{3, F} \cdot a g e_{t}^{h}+\alpha_{4, F} \cdot\left(a g e_{t}^{h}\right)^{2}+v_{F, t, h}, \\
& y_{t, h}^{I}=\alpha_{1, I} \cdot y_{t-1}^{h}+\alpha_{2, I} \cdot e^{h}+\alpha_{3, I} \cdot a g e_{t}^{h}+\alpha_{4, I} \cdot\left(a g e_{t}^{h}\right)^{2}+v_{I, t, h},
\end{aligned}
$$

where $v_{F, t}^{h} \sim N\left(0, \sigma_{F}\right)$ and $v_{I, t}^{h} \sim N\left(0, \sigma_{I}\right)$.

Both specifications relate the labor income offer of household $h$ at $t$ to $h$ 's labor income at $t-1$ plus a linear return to education and a quadratic return to age of the household head. Each parameter is allowed to differ between the two sectors. The shocks of both processes are drawn from different normal distributions.

Municipalities' access to credit from friends and relatives: The only source of uncertainty in the model at the municipality level is the fraction of households with access to credit from friends and relatives. This different access to informal credit captures all municipalities heterogeneity that is not explicitly modeled. This process is modeled to capture that access to informal credit in a municipality should be persistent over time, but sometimes it changes in a municipality and hence, 
Azteca's decision of location could suddenly change as well. As an example, one might interpret this alternative credit as the sudden entrance of other financial competitors of Azteca in a municipality. In addition, to add flexibility to this process, I allow for this unobserved heterogeneity to be correlated to municipalities' income. I use the data from the initial year (2002) to classify each municipality in one of two categories: "low" or "high" fraction of households with access to credit from relatives and friends. Municipalities were considered "with high access" if the fraction of households borrowing from friends and relatives was above the sample mean, otherwise they were grouped as "with low access". Once the access from informal credit was determined for the starting year, at the beginning of each year, every municipality draws its new fraction of households conditional on the $t-1$ fraction of households with access and the income of the municipality. In the model, I discretize municipalities' income $\left(Y^{m}\right)$ into 2 levels (below and above the income means), hence the transition probabilities of access to credit for each municipality take the following form:

$$
\left[\begin{array}{cc}
g^{Y T} & 1-g^{Y T} \\
1-g^{Y T} & g^{Y T}
\end{array}\right],
$$

where $Y$ and $T$ correspond to whether the municipality is low or high income and whether its $t-1$ access was low or high. Hence, municipalities switch their fraction of households with access to informal credit with probability $g^{Y T}$ and remain with the same fraction of households covered with probability $1-g^{Y T}$.

\section{Model Estimation}

There are 24 structural parameters of the model which are estimated by the method of indirect inference proposed in Gourieroux et al. (1993) and Gourieroux and Monfort (1996). The goal of this method is to estimate a vector of structural parameters $\phi$, by matching a set of simulated statistics, denoted as $\mu$, with the corresponding set of actual data statistics, denoted as $m$. The estimated structural parameters are those that minimize the weighted average distance between the set of simulated statistics and the set of data statistics. Because the simulated statistics depend on the underlying structural parameters, minimizing this distance will provide consistent estimates of the structural parameters under certain conditions. The indirect estimator of $\phi$ is defined as the solution to the minimization of

$$
\widehat{\phi}=\arg \min _{\phi}\left[m_{n}-\frac{1}{s} \mu_{n}^{s}(\phi)\right]^{\prime} \widehat{W}_{N}\left[m_{n}-\frac{1}{s} \mu_{n}^{s}(\phi)\right]
$$


where the subscript $n$ refers to the number of households in the sample and $s$ denotes the number of simulations. $\widehat{W}_{N}$ is a positive definite matrix that converges in probability to a deterministic positive definite matrix $W$. I use the inverse of the covariance matrix of the data moments as the weighting matrix $\widehat{W}_{N}$. The covariance matrix is computed using a standard bootstrap method with 1000 bootstraps.

The statistics to be matched are listed in tables 9 and 10, and include summary statistics and OLS regression coefficients. The first four statistics correspond to the proportion of households that belonged to the formal sector in 2005, conditional on the education of their head and on their employment sector in 2004. Statistics from 5 to 14 are related to the labor income process from the formal and informal sectors ${ }^{3}$. Statistic 5 captures the persistence of labor income in the formal sector, by regressing the 2005 labor income of formal households on their 2004 labor income. The next moment captures the returns to education on the formal labor income by computing the mean difference between labor income of low and high educated households that belonged to the formal sector by 2005 . Moments 8 and 9 describe the income returns to age in the formal sector, by comparing the 2005 labor income of households older and younger than 35 and households older and younger than $50^{4}$, conditional on being employed in the formal sector. Moment 10 captures the variance of the income shocks received by formal households in 2005. These shocks are the residuals from the OLS regression of formal labor income in 2005 on 2004 labor income, education, age and age squared for households observed in the formal sector at 2005. The same statistics are used to capture the income process of the informal sector (moments 10 to 14).

The next four moments relate to households' consumption behavior. These moments correspond to the 5th percentile of the distribution of households' percapita expenditure in 2005; the proportion of households that owned radio, TV sets, VCRs or computers in 2005; the 2005 ratio of percapita expenditure to total income across households; and the log of the ratio of percapita expenditure in 2005 to the 2002 percapita expenditure across households. Moment 19 corresponds to the proportion of municipalities that had an Azteca branch in 2005. The next two moments refer to informal credit access. To compute them, I first obtained the 2005 average fraction of households with loans from friends and relatives across municipalities. Moment 20 corresponds to the municipalities that were below this average. It captures the mean proportion of households that got informal loans in these municipalities. Moment 21 refers to the same statistic but using the sample of municipalities who

\footnotetext{
${ }^{3}$ The households' data (MxFLS) includes retrospective information for the years 2004 and 2001 regarding labor decisions, which is used to compute these moments.

${ }^{4}$ In the model, the age of the household corresponds to the age of its head.
} 
were above the average fraction of households with credit from friends or relatives. The last four moments capture the persistence of credit from friends and relatives over time. I computed the average fraction of households across municipalities that got credit from friends and relatives in 2002 and 2005, respectively. I then classified municipalities into two groups: municipalities below the average fraction in 2002 and municipalities above. Moment 22 is the proportion of households that in 2005 obtained an informal loan conditional on low-income municipalities that were below the 2002 mean of credit from friends and relatives. Moment 23 is the proportion of households that in 2005 obtained an informal loan conditional on low-income municipalities that were above the 2002 mean of credit from friends and relatives. Moment 24 is the proportion of households that in 2005 obtained an informal loan conditional on high-income municipalities that were below the 2002 mean of credit from friends and relatives. Moment 25 is the proportion of households that in 2005 obtained an informal loan conditional on high-income municipalities that were above the 2002 mean of credit from friends and relatives.

\section{Estimation results and model fit}

The estimation of the model requires some choices regarding the size of the state space. I discretize households' savings and labor income, the value of the durable goods, the household head's years of schooling, the fraction of households covered by friends and relatives, and the income of the municipalities, which are the continuous state variables of the model. The grids were selected so that they reflect the distributions of these variables in the data. The grid of savings consists of 10 points, the first one equals the 5 th percentile of the empirical savings distribution and the consecutive points refer to the 15 th, 25 th,..., 85 th and 95 th percentiles. I tested the robustness of the simulations using fewer grid points and I found that it is important to include at least 10 points. The value of the durable goods was discretized to 4 point grids. The first point corresponds to a value of $\$ 0$ and the last 3 points reflect the empirical distribution of durable goods value: these points correspond to the 30th, 60th and 90th percentiles of the data distribution. Household heads' years of schooling were discretized into two grid points: the first point corresponds to all household heads with less than 9 years of schooling and the second point includes all households in which the head had 9 or more years of education. At the aggregate level, municipalities were classified by their fraction of households with access to credit from friends and relatives into two categories: below and above the mean fraction of households who borrowed from friends and relatives. Municipalities were also classified in two 
groups according to their percapita income, using the median income as the cut-off. Households' labor income was also discretized using a 3-point grid, whose points correspond to the mean values between the 1st and the 33th percentiles, the 33th and 66th percentiles and above the 66th percentile of the distribution of total labor income. Finally, I approximate the discrete distributions of formal and informal labor income shocks following Kennan (2006). I specify a continuous distribution for each sector shock, and given the parameters of this distribution, I specify a discrete approximation to them. I allow for 3 support points for these discrete approximations.

\subsection{Estimation results}

Table 11 presents the estimated parameters and their asymptotic standard errors. I compute the asymptotic standard errors following Gourieroux et al. (1993) and Gourieroux and Monfort (1996).

Probability parameters of receiving a formal offer: $f_{t}^{h} \mid e^{h}, F_{t-1}^{h}$

Since the probability that a household receives a formal-sector job offer depends on whether the household belonged to the formal sector in the last period and on the education of the household head, $e^{h}$, the model estimates four different probabilities. According to the estimation results, the probability of receiving an offer from the formal sector increases substantially if households were formal in the previous period. For low and high educated households, the estimated probabilities are 0.627 and 0.793 , respectively. Households employed in the informal sector have a lower probability of receiving a formal job offer in the next period. These probabilities are 0.059 for low educated households and 0.126 for high educated ones.

Parameters for formal labor income process: $\alpha_{1, F}, \alpha_{2, F}, \alpha_{3, F}, \alpha_{4, F}, \sigma_{F}$

The labor income process is allowed to depend linearly on previous labor income and education, and concavely on age. The estimated persistence for the formal income is 0.5312 , which means that each period, households income consists of $53 \%$ of their lagged labor income. The returns to education in the formal sector are estimated to 1.26. This coefficient implies that in the formal sector, income of high-educated households is $45.5 \%$ higher than low educated households. Regarding returns to age, the estimated coefficients are 0.04 and -0.0003 . These parameters indicate that the age at which a household employed in the formal sector receives its highest income is 66 years. The estimated standard deviation of the income shocks from the formal sector is 2.305 .

Parameters for informal labor income process: $\alpha_{1, I}, \alpha_{2, I}, \alpha_{3, I}, \alpha_{4, I}, \sigma_{I}$.

According to the estimated model, the persistence of lagged labor income on current income in the informal sector is 0.48 , lower than in the formal sector. The returns to education (0.7) imply that 
relative to households with low education, the income of high-educated households in the informal sector is $58 \%$ higher. The estimated coefficients on age are 0.02 and -0.00018 , respectively. Compared to the formal sector, the peak income age is reached earlier in the informal sector, when households are 56 years old. The standard deviation of the informal income shocks is 2.52, slightly higher than the variance from the formal sector.

\section{Parameters for access to informal credit (credit from friends and relatives): $R_{t}^{m}$}

In the model, access to credit from friends and relatives varies among municipalities. For computational reasons, municipalities are allowed to have two different types of access: low and high. The estimated parameter for low access to informal credit is 0.05 , which implies that in municipalities with low access, only $5 \%$ of households can borrow from friends or relatives if they need to. In municipalities with high coverage, each period $32.1 \%$ of households have a friend or relative from which they can borrow.

Parameters for the transition of fraction of households with access to credit from friends and relatives: $g^{Y T}$

The parameters ruling the transition over time of informal loans are as follows. Low-income municipalities who had low access to informal credit in the previous period, stay with low access to informal credit with probability 0.98 , and experience high access with probability 0.02 . If low-income municipalities previously had high access to informal credit, they stay with high access with probability 0.502 . For high-income municipalities, the transition probabilities are the following. Those municipalities who had low access to informal credit in the previous period, stay with low access with probability 0.927. Municipalities that experienced high access to credit in the past, would remain with high access at $t$ with probability 0.934 .

\section{Households' preferences parameters: $\gamma, \eta_{0} \eta_{1}$.}

The estimated intertemporal substitution of nondurable goods, $\gamma$, is 3.1, which is within the range of what other papers have found. The estimated joint product of $\eta_{0} \eta_{1}$ is 2.1 but given the parametrization, I am not able to identify separately the preference for the service flow of durable goods $\left(\eta_{0}\right)$ from the household productivity $\eta_{1}$.

\section{Banco Azteca's cost of operation: $\chi$.}

The parameter for the Azteca's cost of operation is estimated to 295. This parameter implies that Azteca must pay each year $\$ 29,500 U S D$ to operate each branch.

\section{Consumption floor.}

This parameter determines the minimum consumption that a household receives. Its estimated 
value is 0.4 , which corresponds to a daily percapita consumption of $\$ 0.83 U S D$.

Exogenous parameters. I now discuss the parameters that are not estimated inside the model. Information about interest rates and collateral requirements is considered exogenous in the model. Their values were obtained from CONDUSEF, Azteca's Financial Reports and the households' data. According to this information, the average APRs of pawnshops, Banco Azteca, traditional banks and friends or relatives over the years examined (2002 to 2005) were $220 \%, 130 \%, 40 \%$ and $0 \%$ respectively. Regarding collateral, $90 \%$ of the households in the dataset that obtained credit from friends and relatives reported they were not required to own any collateral, therefore in the model, the collateral that friends and relatives require is set to zero. According to reports from PROFECO, the average collateral required by a pawn shop in Mexico is six times the value of the loan. According to CONDUSEF and Banco Azteca's reports, both Banco Azteca and traditional banks require a collateral equivalent to the value of the loan. The maximum loan that households can borrow from friends and relatives is also determined outside the model. Its value is $\$ 2,000 U S D$, and was obtained from the 95th percentile of the distribution of loans from friends and relatives from the households data. The depreciation of the durable goods, $\delta$, was fixed to 0.10 . The relative price of the durable goods with respect to the consumption goods, $p$, was obtained from the Consumer Price Index in 2002, and was set to $\$ 10$. The discount factor, $\beta$, was fixed to 0.99 .

\subsection{Model Fit}

I now discuss the fit for the selected statistics in the estimation. In general, the estimated model matches closely the simulated statistics to the real ones. Table 12 presents the moments for the share of households employed in the formal sector in 2005, conditional on their education level and previous sector employment. The likelihood of being employed in the formal sector is strongly correlated with having participated in the formal sector in the previous period, for both low and high educated households. But also, regardless of whether households were formal or not in the previous period, education increases the probability of being formal. The simulated moments replicate these data patterns closely. In general, the model fits well the labor income process of households employed in the formal and informal sectors, as tables 13 and 14 show. The next table (table 15) presents other households' statistics. The simulated statistics for the 5th percentile of the distribution of households' percapita consumption, the fraction of households who own durable goods and the consumption moments are close to the data moments. The fit for the last statistics is listed in table 16. The model slightly overpredicts the fraction of municipalities with an Azteca branch in 2005 (0.529 vs 0.51). The 
simulated moments governing the behavior of credit from friends and relatives across municipalities accurately fit the data patterns, and the persistence of the transitions of informal credit over time are also replicated by the simulated statistics.

I now examine the performance of the model in predicting the type of municipalities where the bank locates. Table 17 compares the characteristics of municipalities with Azteca between the simulations and the real data. Information in the first column refers only to municipalities in which Azteca operated from 2002 to 2005 . The second column contains statistics only for municipalities where Azteca located in 2002 but exited before 2005. The third column presents information of municipalities where Azteca entered after 2002 but that by 2005 had an Azteca branch. The fourth column contains information from municipalities where Azteca opened after 2002 and exited before 2005. Finally, the fifth column presents statistics for municipalities that never had an Azteca branch. The table summarizes the following variables at the municipality level: percentiles from the population size and percapita income distributions, a dummy indicator that equals 1 if the municipality has a branch of other bank institution and the total number of municipalities that fall into each category. The first panel of the table reports information from the real data and the second panel reports on the simulated data. We see from the number of municipalities that the model underpredicts municipalities where Azteca operated all periods (63 vs 48) and where Azteca never entered (67 vs 53); and overpredicts the number of municipalities where Azteca entered from 2002 and exited before 2005 (2 vs 6), municipalities where Azteca entered after 2002 but stayed until at least 2005 (4 vs 24) and municipalities where Azteca entered after 2002 and exited before 2005 (0 vs 5). However, the overall pattern of bank branches, distribution of population size and percapita income are matched substantially well.

\section{Robustness of the model}

To examine the performance of the model in reproducing the data patterns that were not used to estimate the structural parameters, I examine if the model can reproduce the change experienced by households from the informal sector in municipalities where Azteca located its branches. To do this, I estimate difference-in-difference regressions in the real and simulated data in which the treated group consists of informal households in municipalities with Azteca branches in 2005. Informal households from all other municipalities are the control group. The regressions compare informal households' outcomes of 2002 (before Azteca existed) with 2005 (once Azteca had operated for 3 years). The 
outcomes examined refer to the probabilities that informal households obtained loans from banks and from pawn shops, and the probability that these households saved.

Tables 18 to 20 present the results. The first column in the tables shows the real data difference-indifference specification. The second column presents the simulated difference-in-difference regression. The last column presents an alternative specification of the simulated difference-in-difference regression. In the households data, the 1st percentile of bank and pawnshop loans is $\$ 30 U S D$ and $\$ 10 U S D$, respectively. Since in the model saving is a continuous variable, in this specification I constrain the simulated variables using these cutoffs. Hence, I consider that households borrowed from banks / pawnshops if they borrowed at least $\$ 30 U S D / \$ 10 U S D$.

Table 18 presents the comparison of the difference-in-difference outcomes on the probability that a household obtained a loan from banks. The coefficient of interest is the interaction of the variables azteca (a dummy that equals one if the municipality had an Azteca over the period and zero otherwise) and year (an indicator variable that equals one if the year is 2005 and 0 if the year is 2002), this coefficient is denoted as azteca*year. According to the data patterns, informal households were more likely to obtain bank loans once Azteca entered into their municipalities. This probability increased in 0.0109 , which implies an increase of more than 100\% from their 2002 mean. The model is able to reproduce this pattern, but it overestimates the size of the coefficient of interest. Once savings and loans are constrained by the cutoffs from the real data, the simulated DID coefficient decreases to 0.0155, which is closer to the data coefficient.

Table 19 shows the probability that informal households obtained loans from pawnshops. According to the real data, relative to informal households from municipalities where Azteca did not open during all periods, this probability declined in 0.011 points for informal households in municipalities with Azteca branches, which corresponds to a reduction of $50 \%$ in the mean pawnshop credit usage of informal households by 2002. The model is able to reproduce this pattern, but underestimates the magnitude of the coefficient ( 0.0038 which corresponds to a decline of $36 \%$ ).

Table 20 shows the probability that informal households save. In the real data, this probability is -0.031 , which implies that the proportion of informal households who saved declined once Azteca located its branches in their municipalities, relative to informal households from other municipalities. Simulations of the model capture that the probability of saving declined in municipalities where Azteca entered. Although the magnitude of the simulated DID is larger (0.12 vs 0.03$)$, compared to the 2002 mean, the percentage change in municipalities with Azteca is similar in the model to that in the data $(14 \%$ vs $11 \%)$. 


\section{Quantification of the Impact of Banco Azteca}

\subsection{Estimating the Impact of Banco Azteca on households' outcomes}

The estimated model suggests that the presence of Azteca alters households' decisions regarding credit, savings and durable goods acquisition, and also enhances households' consumption smoothing. In this section I discuss which households concentrate these effects and quantify the size of these changes. I quantify the effects of Banco Azteca only on households from municipalities where Azteca decided to enter. To do this, I compare the model simulations with simulations in which Azteca never operates branches.

Saving patterns Figure 1 describes the average savings of households at different income deciles under two cases: with and without Azteca. According to this table, once Azteca's credit is available in municipalities, lower income households decide to save less. Moreover, figure 2 shows that the fraction of households saving also declines with the presence of this bank. On average, the fraction of households saving declined by $5.8 \%$. Regarding credit choices, figures ?? and ?? present the share of households obtaining loans from Banco Azteca and pawnshops across income deciles. From these figures we first see that usage of Azteca and pawnshop loans is concentrated among lower income households. Additionally, once Azteca's branches are available in the municipality, the share of households borrowing from pawn shops declined.

Consumption of Durable and Nondurable goods Figure 5 presents the average value of durable goods across income deciles with and without Azteca's presence. The value of durable goods owned by low-income households is higher in simulations that allow for Azteca branches. Consumption of nondurable goods, however, remains unchanged once Azteca operates its branches.

Consumption Smoothing I now discuss whether households are better able to smooth their consumption from income fluctuations over time, when credit from Azteca is available in their municipalities. To analyze consumption smoothing of households over time, I adapt the index proposed in Mazzocco and Saini (2008). The consumption smoothing index is defined as follows:

$$
I=\frac{\operatorname{Var}\left(y^{h}\right)-\operatorname{Var}\left(c^{h}\right)}{\operatorname{Var}\left(y^{h}\right)}
$$

where $\operatorname{Var}\left(y^{h}\right)$ and $\operatorname{Var}\left(c^{h}\right)$ correspond to the labor income and consumption variances of household $h$ over time. This index $(I)$ takes values from 0 to 1 . See for example the extreme case in which 
households' consumption equals their labor income each period. In this case the numerator would equal zero, and hence, $I=0$. If households smooth their consumption entirely, then each period households would consume the same amount, $\operatorname{Var}\left(c^{h}\right)$ would equal zero and $I=1$. Therefore, the higher the index, the better able are households smoothing their consumption. Table 23 presents the mean of this index for households with and without Banco Azteca. Households' index is 0.168 when the model is simulated without Azteca in their municipalities. When I simulate the model allowing for the presence of Azteca, households' consumption smoothing index increases to 0.19, implying an increase of the index of $12 \%$.

\subsection{Difference-in-difference estimates using control group vs simulated treatment group with no Azteca intervention}

Since the entrance of Banco Azteca did not occur randomly across municipalities, difference-indifference (DID) estimations that compare municipalities chosen by the bank with other municipalities are likely to be biased if we fail to account for all the observable and unobservable characteristics that made Azteca decide its location. One advantage of the model is that it can be used to measure this bias. To do this, I use the simulated data to estimate DID regressions using as a control group: households from municipalities that did not have an Azteca branch by 2005 and households from the same municipalities where Azteca entered under the scenario that Azteca never entered. To measure the size of the bias, I then compare the DID estimates. I now discuss the results.

Tables 21 and 22 compare the simulated DID regressions. In both regressions, the treated group is the same: informal households from municipalities with Azteca branches in 2005. The control groups are different. The first column shows the DID specifications using as control group informal households from municipalities without Azteca in 2005. DID estimates using the second control group are shown in column 2. This alternative control group consists of informal households from municipalities chosen by Azteca under the scenario that Azteca never entered. The second control group must be the adequate control, since it consists of the same households but without Azteca's presence. According to the model results, using the correct control group yields lower estimates on the DID results than using households from other municipalities where Azteca never entered. These results suggest that comparing households from municipalities with Azteca with households from municipalities without the bank might overestimate the real impact of Banco Azteca, since in the absence of this bank, households from the treated municipalities were less likely to use pawnshops loans and keep savings than households from municipalities where Azteca chose never to open. 


\section{Policy Evaluation}

I now discuss the policy experiment, which consists of capping the interest rate that Banco Azteca charges and examine how Azteca's location choices change. Capping the interest rates of formal credit institutions has been suggested by several Mexican policy makers who are opposed to excessive interest rates charged to households. This policy however, could have the unintended effect of making Azteca re-locate its branches and exit from municipalities where it currently operates. As the model includes Azteca's location choices, it is well suited to analyze this issue.

I simulate the model at different APRs charged by Azteca to examine changes in household credit requests, average loan size and Banco Azteca selection of municipalities. In the model, Azteca locates in municipalities based on its expected profits, which depend on households' demand for Azteca's loans. The number of households that obtain Azteca's credit and the amount borrowed by these households must react to different APRs. Therefore, driven by these responses, Azteca's selection of municipalities can change.

I now discuss how households' demand for Azteca's credit reacts as the APR declines. Figure 10 presents the average size of loans conditional on obtaining Azteca's credit and the proportion of households that use Azteca's credit at different APRs. As the APR declines, the fraction of households requesting Azteca's credit increases. At an APR of 130\%, 5.7\% of households obtain credit from Azteca, while at an APR of $40 \%$, this number increases to $10.1 \%$. Using the midpoint elasticity formula, the extensive price elasticity of demand for Azteca's credit is -0.52 . We can see from the figure that the average size of loans for households that obtain credit from Azteca is also sensitive to changes in the APR. The average loan of households borrowing from Azteca at an APR of $130 \%$ is $\$ 76.2$ USD. This average increases to $\$ 105.5$ USD when the APR charged is $40 \%$. These results indicate that the elasticity of loan size with respect to price is - .304. These results are comparable to Karlan and Zinman (2008) who under a completely different setting found from a randomized trial in South Africa an extensive elasticity of demand for consumer credit of -0.28 and a price elasticity of loan size demand of -0.11 . Although the elasticities that I find are larger, they are consistent with an inelastic response of households to changes in the price of credit.

At the current APR, Azteca locates in 0.51 of all municipalities. However, as the APR that Azteca charges decreases, the number of municipalities with Azteca's branches falls (Figure 11). At an APR of $40 \%$, which represents a plausible ceiling since it is closer to traditional banks' rates, Azteca would only open in $44 \%$ of the sampled municipalities. Figures 12 and 13 provide information regarding 
the average population size and percapita income of municipalities where Azteca would locate at different APRs. As seen in Figure 12, As Azteca's APR decreases, the average population size of municipalities with Banco Azteca increases. This implies that at lower APRs, Azteca would exit from less populated municipalities and would locate in the more populated ones. The same pattern is observed when examining the percapita income of municipalities with Azteca's branches. At lower APRs, Azteca's branches would concentrate in wealthier municipalities. Altogether, these results suggest that if Banco Azteca were forced to charge lower rates and no other adjustment is done, households from poorer and smaller municipalities would lose their Azteca branches.

\section{Conclusions}

This paper examined the impact of expanding access to credit on the decisions and welfare of households. To do so, the paper focused on the opening of Banco Azteca, the first bank in Mexico that targeted households whose members belong to the informal sector. A comparison of household outcomes from municipalities where this bank opened with other municipalities suggests that households, especially those employed in the informal sector, experienced significant changes in their saving, credit and consumption patterns. In order to address the impact of Banco Azteca and the issue of endogenous location of its branches, I developed a model of household choices in which the bank endogenously selects municipalities for branch openings.

I used the model to quantify the impact of Banco Azteca. I find substantial effects on household saving and consumption decisions once access to credit is available. First, households increased their bank credit usage and decreased loans from other more expensive suppliers, such as pawn shops. Second, in municipalities with presence of Azteca branches, the fraction of households saving declined. These effects were sharper for households at lower income deciles, and suggest that the use of savings as a buffer on income fluctuations declined once formal credit was available. Simulations of the model indicate that consumption smoothing improved once households had access to credit from Azteca. Consistent with the targeted population of Banco Azteca, informal households experienced most changes.

I then use the estimated model to evaluate the effect of capping the APR that Azteca currently charges on household demand for credit and Azteca's location choices. Several policy makers in Mexico have suggested imposing a ceiling on the interest rates of formal credit institutions in order to make loans more affordable to people. The model simulations indicate that if the APR that Azteca 
charges were capped to $40 \%$, both the fraction of households obtaining Azteca loans and the average loan size of those borrowing would increase. Nevertheless, this increase in demand would not compensate for the reduction in APR, and $14 \%$ of municipalities that currently have branches of this bank would lose them. The likelihood of losing a branch is higher for poorer and less populated municipalities. 


\section{References}

Banerjee, A., E. Duflo, R. Glennerster, and C. Kinnan (2009). The miracle of microfinance. Evidence from a randomized evaluation.

Bruhn, M. and I. Love (2009). The economic impact of banking the unbanked: evidence from Mexico. Policy Research Working Paper Series.

Burgess, R. and R. Pande (2005). Do rural banks matter? Evidence from the Indian social banking experiment. American Economic Review 95(3), 780-795.

Gourieroux, C. and A. Monfort (1996). Simulation-based econometric methods. Oxford University Press, USA.

Gourieroux, C., A. Monfort, and E. Renault (1993). Indirect inference. Journal of Applied Econometrics $8(\mathrm{~S} 1)$, S85-S118.

Kaboski, J. and R. Townsend (2008). A Structural Evaluation of a Large\% Scale Quasi\% Experimental Microfinance Initiative.

Karlan, D. and J. Zinman (2008). Credit elasticities in less-developed economies: Implications for microfinance. The American Economic Review 98(3), 1040-1068.

Keane, M. and K. Wolpin (1994). The solution and estimation of discrete choice dynamic programming models by simulation and interpolation: Monte Carlo evidence. The Review of Economics and Statistics, 648-672.

Kennan, J. (2006). A note on discrete approximations of continuous distributions. University of Wisconsin Madison.

Mazzocco, M. and S. Saini (2008). Testing Efficient Risk Sharing with Heterogeneous Risk Preferences. Department of Economics, University of Wisconsin at Madison Working Paper. 
Municipalities characteristics by presence of Banco Azteca

\begin{tabular}{cccccc}
\hline Variable All muns & $\begin{array}{c}\text { from 02 } \\
\text { to 05 }\end{array}$ & $\begin{array}{c}\text { from 02 } \\
\text { before 05 }\end{array}$ & $\begin{array}{c}\text { after 02 } \\
\text { until 05 }\end{array}$ & $\begin{array}{c}\text { no Azteca's } \\
\text { branches }\end{array}$
\end{tabular}

Population size

$\begin{array}{lccccc}p 10 & 9,413 & 57,375 & 62,773 & 47,106 & 4,318 \\ p 25 & 19,475 & 78,512 & 62,773 & 50,168 & 10,644 \\ p 50 & 59,675 & 227,026 & 63,319 & 57,602 & 19,447 \\ p 75 & 226,642 & 516,255 & 63,864 & 366,068 & 41,402 \\ p 90 & 609,829 & 1,110,997 & 63,864 & 670,162 & 69,381\end{array}$

Percapita Income

\begin{tabular}{cccccc}
$p 10$ & 18,789 & 31,642 & 48,436 & 25,375 & 15,100 \\
$p 25$ & 28,687 & 38,561 & 48,436 & 26,349 & 22,908 \\
$p 50$ & 37,136 & 50,912 & 48,876 & 31,308 & 30,434 \\
$p 75$ & 54,551 & 66,846 & 49,317 & 57,985 & 37,044 \\
$p 90$ & 71,967 & 76,379 & 49,317 & 80,676 & 50,423 \\
& & & & & \\
Other banks & 0.71 & 0.98 & 1.00 & 1.00 & 0.43 \\
\# muns & 136 & 63 & 2 & 4 & 67 \\
& & & & & \\
\hline
\end{tabular}

Table 1: Information from the 136 municipalities of the sampled households. Data from the 10th to 90th percentiles of population size and percapita income of municipalities is obtained from the 2000 Mexican Census and the Human Development Index of Mexican Municipalities. Information on the presence of other traditional bank branches is obtained from the CNBV data. Municipalities are classified by their presence of Azteca: municipalities in which Azteca entered on 2002 and stayed until at least 2005; municipalities in which Azteca entered after 2002 but stayed until at least 2005; municipalities where the bank entered by 2002 but exited before 2005; and municipalities where the bank never decided to open branches. 
Number of households

2002

2005

Fraction of formal hhds

2002

2005

$\begin{array}{cc}0.238 & 0.131 \\ (0.426) & (0.337) \\ 0.229 & 0.125 \\ (0.421) & (0.331)\end{array}$

Fraction of hhds whose head is unemployed

2002

2005

$\begin{array}{cc}0.064 & 0.036 \\ (0.250) & (0.188) \\ 0.079 & 0.055 \\ (0.271) & (0.225)\end{array}$

Fraction of informal hhds whose head is unemployed 2002

2005

Fraction of formal hhds whose head is unemployed 2002

$3483 \quad 2156$

$3470 \quad 2146$$$
(0.271)-(0.225)
$$

$\begin{array}{cc}0.067 & 0.037 \\ (0.230) & (0.186) \\ 0.080 & 0.053 \\ (0.263) & (0.244)\end{array}$

2005

Table 2: Sample restricted to households with information in 2002 and 2005, whose household head is between 18 and 65 years old. Table reports household means for 2002 and 2005, with standard deviations in parentheses. Column 1 presents sample of households from municipalities with an Azteca branch in 2005. Column 2 shows households from municipalities without Azteca branches in 2005. Fraction of formal households is a dummy variable that equals one if households' nuclear members- household head, spouse and sons or daughters- have a job that provides Social Security benefits. Fraction of hhds whose head is unemployed is a dummy variable that equals one if household reported business failure or unemployment of the head. 
Saving patterns of all households

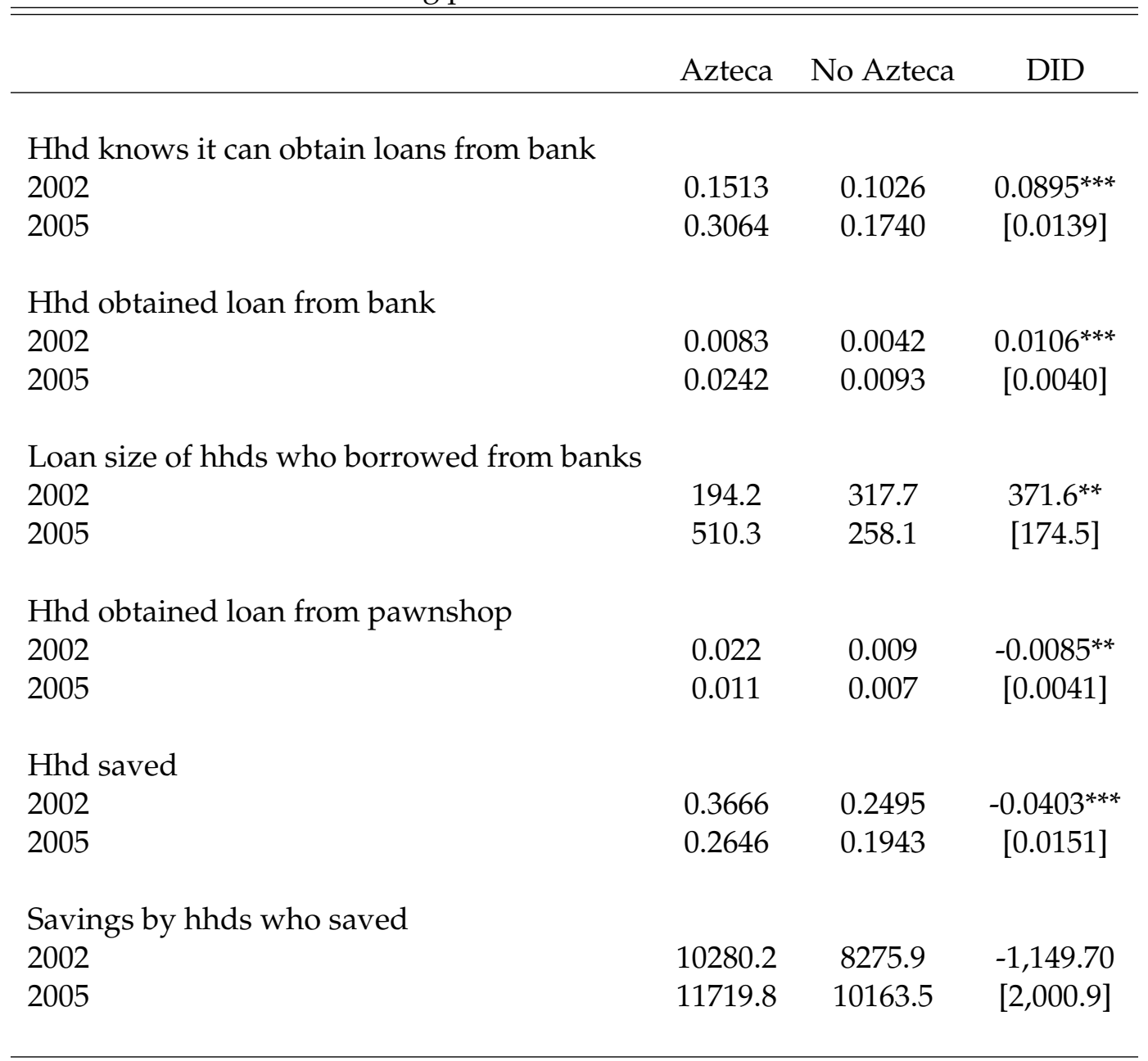

Table 3: Sample restricted to households with information in 2002 and 2005, whose household head is between 18 and 65 years old. Columns 1 and 2 report means for Azteca and non-Azteca municipalities for 2002 and 2005. Column 3 presents the difference-in-difference (DID) estimates and the standard errors in parentheses. saving is a dummy equal to one if household reports saving, 0 otherwise. loan size of hhds and savings by hhds are measured in Mexican pesos. Hhd knows it can obtain loans from bank, Hhd obtained loan from bank, Hhd obtained loan from pawnshop, Hhd saved are indicator variables. 
Consumption patterns of all households

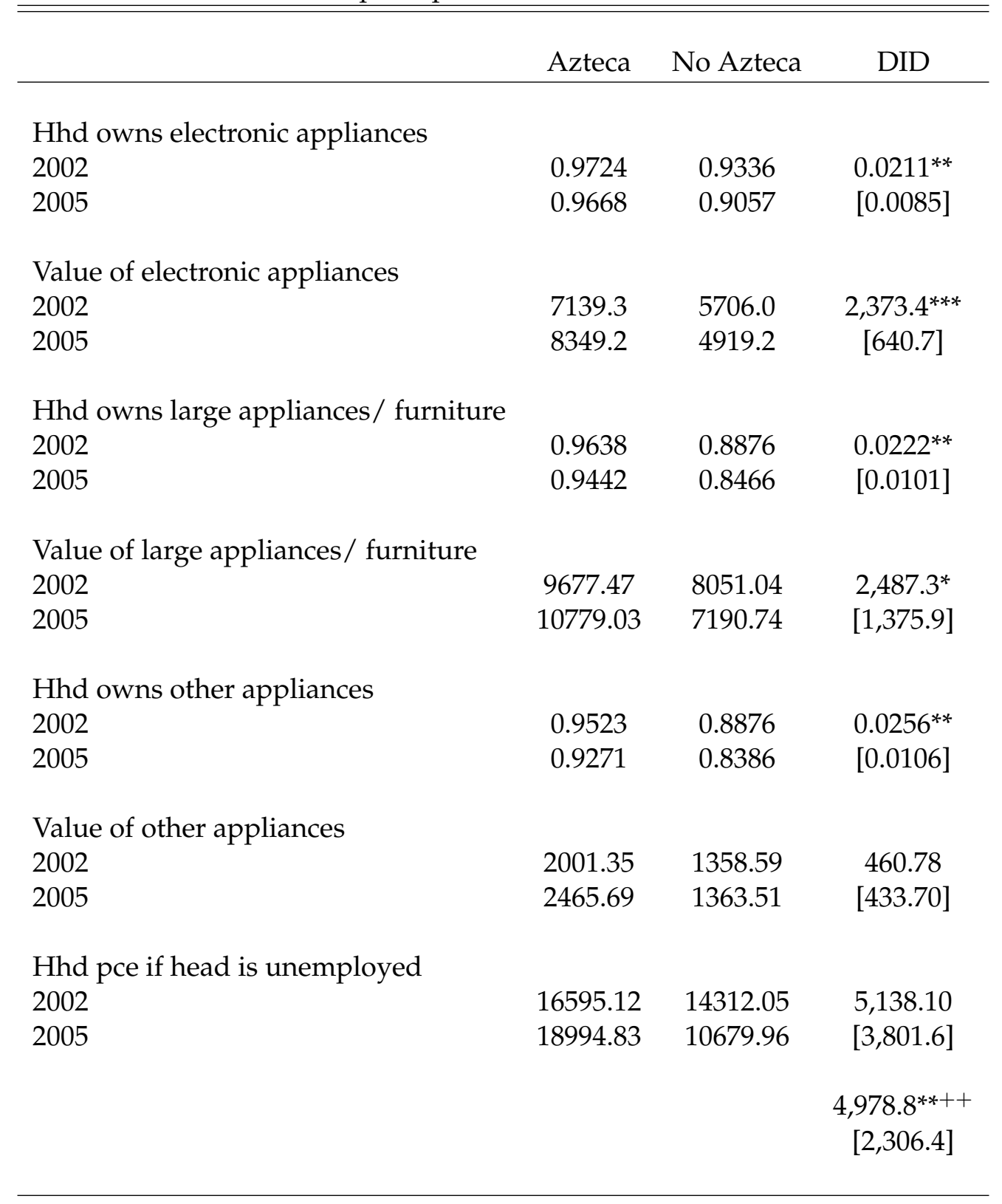

Table 4: Sample restricted to households with information in 2002 and 2005, whose household head is between 18 and 65 years old. Columns 1 and 2 report means for Azteca and non-Azteca municipalities for 2002 and 2005. Column 3 presents the difference-in-difference (DID) estimates and the standard errors in parentheses. Hhd owns electronic appliances, Hhd owns large appliances/furniture and Hhd owns other appliances are dummy variable that equal one if hhd reports owning these goods and zero otherwise. Value of electronic appliances, Value of large appliances/ furniture, Value of other appliances and Hhd pce if head is unemployed are measured in Mexican pesos. ++: DID estimates without household fixed effects. 
Saving patterns of informal households

\begin{tabular}{lccc}
\hline \hline & & & \\
& Azteca & No Azteca & DID \\
\hline Hhd knows it can obtain loans from bank & & & \\
2002 & 0.1322 & 0.0966 & $0.1008^{* * *}$ \\
2005 & 0.2761 & 0.1537 & {$[0.0158]$} \\
& & & \\
Hhd obtained loan from bank & & & \\
2002 & 0.0064 & 0.0037 & $0.0137^{* * *}$ \\
2005 & 0.0232 & 0.0075 & {$[0.0045]$} \\
& & & \\
Loan size of hhds who borrowed from banks & & & \\
2002 & 175.1 & 296.6 & $494.01^{* *}$ \\
2005 & 519.0 & 209.9 & {$[216.02]$} \\
Hhd obtained loan from pawnshop & & & \\
2002 & 0.022 & 0.007 & $-0.0101^{* *}$ \\
2005 & 0.010 & 0.006 & {$[0.0047]$} \\
Hhd saved & & & \\
2002 & & & \\
2005 & 0.3333 & 0.2225 & $-0.0366^{* *}$ \\
Savings by hhds who saved & 0.2290 & 0.1677 & {$[0.0172]$} \\
2002 & & & \\
2005 & 9951.0 & 7540.1 & $-4,736.6^{*}$ \\
& 10481.2 & 9547.9 & {$[2,738.5]$} \\
\hline
\end{tabular}

Table 5: Sample restricted to households from the informal sector with information in 2002 and 2005, whose household head is between 18 and 65 years old. Columns 1 and 2 report means for Azteca and non-Azteca municipalities for 2002 and 2005. Column 3 presents the difference-in-difference (DID) estimates and the standard errors in parentheses. DID estimates include household fixed effects and control for education of household head, if household is in rural village, size of municipality and presence of traditional bank branches or other government credit institutions. DID Standard errors are clustered at the household level. saving is a dummy equal to one if household reports saving, 0 otherwise. loan size of hhds and savings by hhds are measured in Mexican pesos. Hhd knows it can obtain loans from bank, Hhd obtained loan from bank, Hhd obtained loan from pawnshop, Hhd saved are indicator variables. 
Consumption patterns of informal households

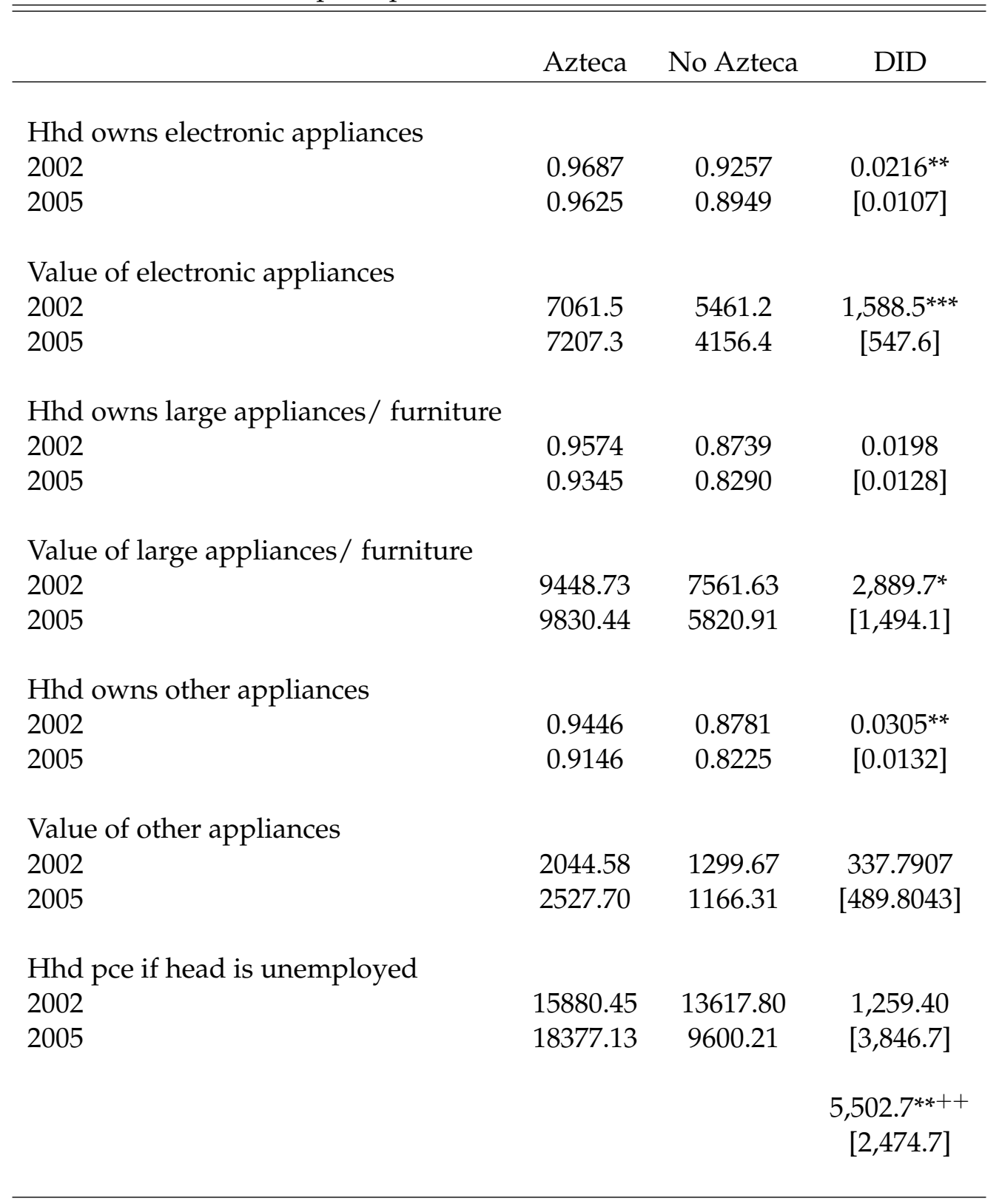

Table 6: Sample restricted to households from the informal sector with information in 2002 and 2005, whose household head is between 18 and 65 years old. Columns 1 and 2 report means for Azteca and non-Azteca municipalities for 2002 and 2005. Column 3 presents the difference-in-difference (DID) estimates and the standard errors in parentheses. DID estimates include household fixed effects and control for education of household head, if household is in rural village, size of municipality and presence of traditional bank branches or other government credit institutions. DID Standard errors are clustered at the household level. Hhd owns electronic appliances, Hhd owns large appliances/ furniture and Hhd owns other appliances are dummy variable that equal one if hhd reports owning these goods and zero otherwise. Value of electronic appliances, Value of large appliances/ furniture, Value of other appliances and Hhd pce if head is unemployed are measured in Mexican pesos. ++: DID estimates without household fixed effects. 
Saving patterns of formal households

\begin{tabular}{lccc}
\hline \hline & & & \\
& Azteca & No Azteca & DID \\
\hline Hhd knows it can obtain loans from bank & & & \\
2002 & 0.2121 & 0.1418 & 0.0114 \\
2005 & 0.4056 & 0.3146 & {$[0.0625]$} \\
Hhd obtained loan from bank & & & \\
2002 & 0.0145 & 0.0071 & -0.0136 \\
2005 & 0.0276 & 0.0224 & {$[0.0190]$} \\
& & & \\
Loan size of hhds who borrowed from banks & & & \\
2002 & 262.2 & 468.6 & -26.9 \\
2005 & 479.5 & 622.1 & {$[351.6]$} \\
Hhd obtained loan from pawnshop & & & \\
2002 & & & \\
2005 & 0.023 & 0.021 & 0.0164 \\
Hhd saved & 0.014 & 0.011 & {$[0.0235]$} \\
2002 & & & \\
2005 & & & \\
Savings by hhds who saved & 0.4734 & 0.4291 & -0.0157 \\
2002 & 0.3844 & 0.3806 & {$[0.0700]$} \\
2005 & & & \\
& & & \\
\hline
\end{tabular}

Table 7: Sample restricted to households from the formal sector with information in 2002 and 2005, whose household head is between 18 and 65 years old. Columns 1 and 2 report means for Azteca and non-Azteca municipalities for 2002 and 2005. Column 3 presents the difference-in-difference (DID) estimates and the standard errors in parentheses. DID estimates include household fixed effects and control for education of household head, if household is in rural village, size of municipality and presence of traditional bank branches or other government credit institutions. DID Standard errors are clustered at the household level. saving is a dummy equal to one if household reports saving, 0 otherwise. loan size of hhds and savings by hhds are measured in Mexican pesos. Hhd knows it can obtain loans from bank, Hhd obtained loan from bank, Hhd obtained loan from pawnshop, Hhd saved are indicator variables. 
Consumption patterns of formal households

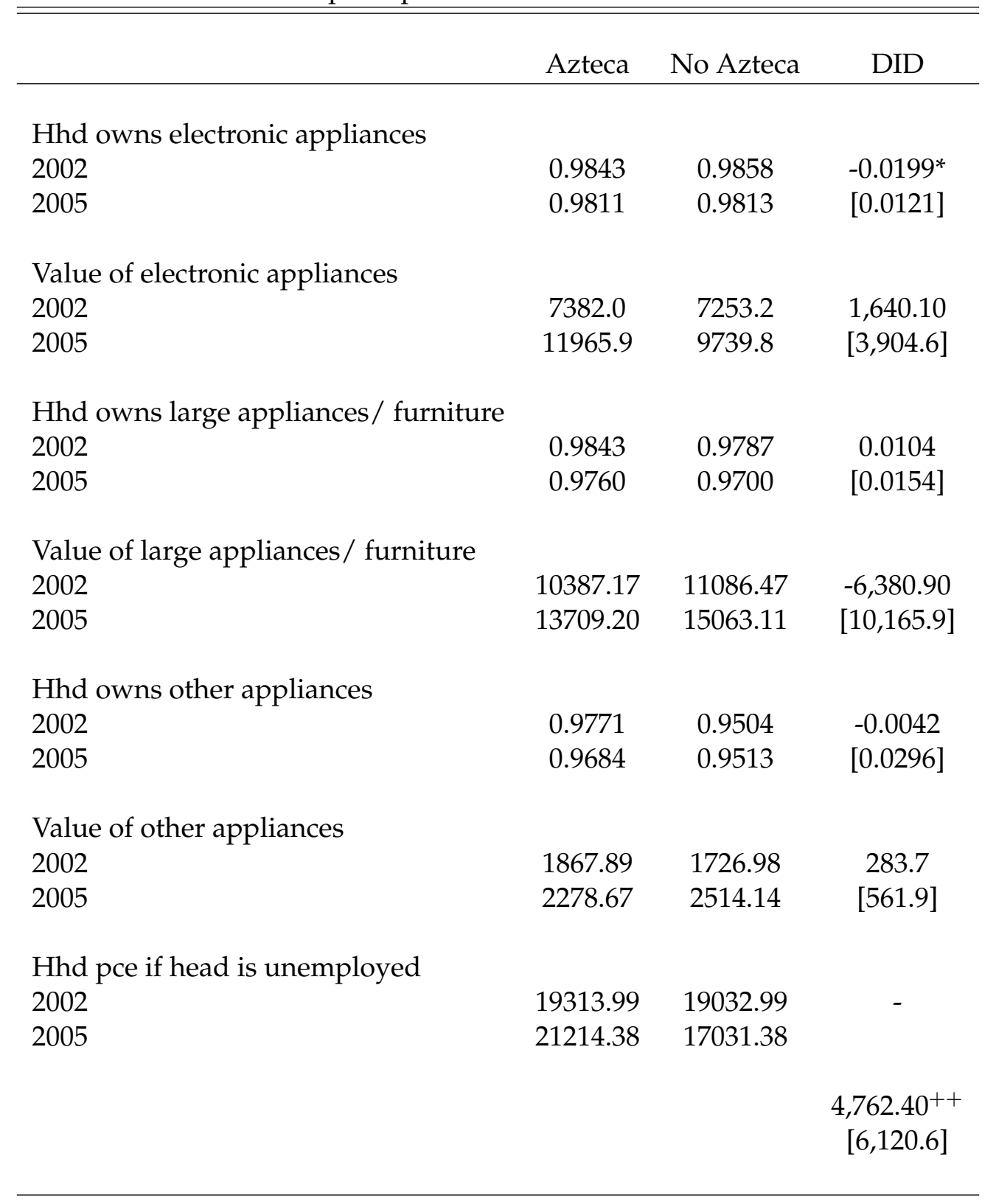

Table 8: Sample restricted to households from the formal sector with information in 2002 and 2005, whose household head is between 18 and 65 years old. Columns 1 and 2 report means for Azteca and non-Azteca municipalities for 2002 and 2005. Column 3 presents the difference-in-difference (DID) estimates and the standard errors in parentheses. DID estimates include household fixed effects and control for education of household head, if household is in rural village, size of municipality and presence of traditional bank branches or other government credit institutions. DID Standard errors are clustered at the household level. Hhd owns electronic appliances, Hhd owns large appliances/ furniture and Hhd owns other appliances are dummy variable that equal one if hhd reports owning these goods and zero otherwise. Value of electronic appliances, Value of large appliances/furniture, Value of other appliances and Hhd pce if head is unemployed are measured in Mexican pesos. ++: DID estimates without household fixed effects. 
Moments Used in the Estimation of the Model

Fraction of households in the formal sector at 2005 by

1) Employment in informal sector at 2004 and less than highschool

2) Employment in informal sector at 2004 and at least highschool

3) Employment in formal sector at 2004 and less than highschool

4) Employment in formal sector at 2004 and at least highschool

Formal sector total income

(sample of formal households at 2005)

5) OLS coefficient of past labor income on current labor income

6) Difference between mean income of low-educated households and high-educated households

7) Difference between mean income of households with head older than 35 and households with head younger than 35

8) Difference between mean income of households with head older than 50 and households with head younger than 50

9) Variance of the residuals from OLS regression of labor income

on past labor income, education and age of the household head

\section{Informal sector labor income}

(sample of informal households at 2005)

10) OLS coefficient of past labor income on current labor income

11) Difference between mean income of

low-educated households and high-educated households

12) Difference between mean income of households with head

older than 35 and households with head younger than 35

13) Difference between mean income of households with head older than 50 and households with head younger than 50

14) Variance of the residuals from OLS regression of labor income on past labor income, education and age of the household head

Table 9: 
Moments used in the Estimation of the Model (Cont.)

\section{Other household statistics}

15) 5th percentile of the households' percapita expenditure distribution

16) Fraction of households that own radio, TV sets, VCR, computers

17) Average ratio of percapita expenditure to total labor income in 2005

18) Average logarithmic ratio of percapita expenditure

in 2005 to percapita expenditure in 2002

\section{Statistics at the municipality level in 2005}

19) Proportion of municipalities with an Azteca branch

20) Fraction of households with friends/relatives loans in muns below the mean fraction of credit from friends/relatives

21) Fraction of households with friends/relatives loans in muns above the mean fraction of credit from friends/relatives

22) - 25) Fraction of loans from friends and relatives in low/high income muns below/above the mean fraction of credit from friends/relatives

Table 10: 


\begin{tabular}{|c|c|c|}
\hline & param & ASE \\
\hline \multicolumn{3}{|l|}{ Probability of job offer from the formal sector } \\
\hline Low educated households, informal sector at $\mathrm{t}-1$ & 0.0589 & 0.00073 \\
\hline Low educated households, formal sector at $\mathrm{t}-1$ & 0.6269 & 0.01825 \\
\hline High educated households, informal sector at $\mathrm{t}-1$ & 0.1255 & 0.00053 \\
\hline High educated households, formal sector at $\mathrm{t}-1$ & 0.7927 & 0.00058 \\
\hline \multicolumn{3}{|l|}{ Labor income from the formal sector } \\
\hline Persistence of lagged labor income & 0.5312 & 0.00189 \\
\hline Returns to education & 1.2698 & 0.00190 \\
\hline Returns to age & 0.0400 & 0.00041 \\
\hline Returns to age squared & -0.0003 & 0.00003 \\
\hline St dev of residuals & 2.3052 & 0.00304 \\
\hline \multicolumn{3}{|l|}{ Labor income from the informal sector } \\
\hline Persistence of lagged labor income & 0.4800 & 0.00276 \\
\hline Returns to education & 0.7000 & 0.00401 \\
\hline Returns to age & 0.0200 & 0.00052 \\
\hline Returns to age squared & -0.0002 & 0.00004 \\
\hline St dev of residuals & 2.5200 & 0.00442 \\
\hline \multicolumn{3}{|l|}{ Credit from friends and relatives } \\
\hline$\%$ households covered in muns with low access & 0.0500 & 0.00025 \\
\hline$\%$ households covered in muns with high access & 0.3213 & 0.00070 \\
\hline \multicolumn{3}{|l|}{ Prob of high access to loans from friends/relatives } \\
\hline If low access at $\mathrm{t}-1$ and low-income mun & 0.0205 & 0.00002 \\
\hline If high access at $\mathrm{t}-1$ and low-income mun & 0.5021 & 0.00329 \\
\hline If low access at $\mathrm{t}-1$ and high-income mun & 0.0730 & 0.00010 \\
\hline If high access at $\mathrm{t}-1$ and high-income mun & 0.9344 & 0.00207 \\
\hline \multicolumn{3}{|l|}{ Utility parameters } \\
\hline Intertemporal substitution of the nondurable good & 3.1000 & 0.00427 \\
\hline Preference from durable goods service flow & 2.1000 & 0.00235 \\
\hline \multicolumn{3}{|l|}{ Other parameters } \\
\hline Azteca's fixed cost & 295 & 12.48 \\
\hline consumption floor & 0.4000 & 0.00384 \\
\hline
\end{tabular}

Table 11: Column 2 presents the structural parameters of the model estimated by Indirect Inference. Column 3 shows the asymptotic standard errors of the parameters. 
Model Fit: Fraction of households employed in the formal sector at 2005

\begin{tabular}{lcc}
\hline \hline & & \\
conditional on: & model & data \\
\hline & & \\
Informal at 2004 and low educated & 0.043 & 0.046 \\
Informal at 2004 and high educated & 0.459 & 0.515 \\
Formal at 2004 and low educated & 0.108 & 0.109 \\
Formal at 2004 and high educated & 0.731 & 0.714
\end{tabular}

Table 12:

Model Fit: Labor Income of households from the formal sector at 2005

\begin{tabular}{lcc}
\hline \hline & & \\
& model & data \\
\hline OLS coefficient of $y_{t}^{h}$ on $y_{t-1}^{h}$ & 0.488 & 0.432 \\
$\sum_{h=1}^{H}\left(y_{t}^{h} \mid e^{h}=1\right)-\sum_{h=1}^{H}\left(y_{t}^{h} \mid e^{h}=0\right)$ & 1.791 & 1.925 \\
$\sum_{h=1}^{H}\left(y_{t}^{h} \mid a g e^{h} \geq 35\right)-\sum_{h=1}^{H}\left(y_{t}^{h} \mid a g e^{h}<35\right)$ & 0.191 & 0.151 \\
$\sum_{h=1}^{H}\left(y_{t}^{h} \mid a g e^{h} \geq 50\right)-\sum_{h=1}^{H}\left(y_{t}^{h} \mid a g e^{h}<50\right)$ & -0.219 & 0.015 \\
$\operatorname{Var}\left(\widehat{v}_{F, t}^{h}\right)$ & 2.071 & 2.478 \\
\end{tabular}

Table 13:

Model Fit: Labor Income of households from the informal sector at 2005

\begin{tabular}{lcc}
\hline \hline & & \\
& model & data \\
\hline & & \\
OLS coefficient of $y_{t}^{h}$ on $y_{t-1}^{h}$ & 0.405 & 0.435 \\
$\sum_{h=1}^{H}\left(y_{t}^{h} \mid e^{h}=1\right)-\sum_{h=1}^{H}\left(y_{t}^{h} \mid e^{h}=0\right)$ & 1.035 & 0.876 \\
$\sum_{h=1}^{H}\left(y_{t}^{h} \mid a g e^{h} \geq 35\right)-\sum_{h=1}^{H}\left(y_{t}^{h} \mid a g e^{h}<35\right)$ & 0.132 & 0.027 \\
$\sum_{h=1}^{H}\left(y_{t}^{h} \mid a g e^{h} \geq 50\right)-\sum_{h=1}^{H}\left(y_{t}^{h} \mid a g e^{h}<50\right)$ & -0.170 & -0.211 \\
$\operatorname{Var}\left(\widehat{v}_{I, t}^{h}\right)$ & 2.057 & 2.097 \\
\end{tabular}

Table 14: 
Model Fit: Other households statistics at 2005

\begin{tabular}{lcc}
\hline \hline & & \\
& model & data \\
\hline 5th percentile of the hhds' consumption & 0.400 & 0.389 \\
Fraction of hhds that own durable goods & 0.873 & 0.958 \\
Avg ratio of $c_{2005}^{h}$ to $y_{2005}^{h}$ & 0.976 & 0.717 \\
Avg log ratio of $c_{2005}^{h} / y_{2005}^{h}$ & -0.172 & -0.130 \\
\hline
\end{tabular}

Table 15:

Model Fit: Statistics at the municipality level in 2005

\begin{tabular}{|c|c|c|}
\hline & model & data \\
\hline$\%$ of muns with an Azteca branch & $52.9 \%$ & $51.0 \%$ \\
\hline \multicolumn{3}{|l|}{ fraction of hhds with informal credit in muns: } \\
\hline below the mean fraction of informal credit & 0.010 & 0.019 \\
\hline above the mean fraction of informal credit & 0.092 & 0.104 \\
\hline \multicolumn{3}{|c|}{ fraction of informal loans at 2005 in low-income muns with: } \\
\hline fraction below mean of informal credit in 2002 & 0.014 & 0.060 \\
\hline fraction above mean of informal credit in 2002 & 0.034 & 0.086 \\
\hline \multicolumn{3}{|c|}{ fraction of informal loans at 2005 in high-income muns with: } \\
\hline fraction below mean of informal credit in 2002 & 0.025 & 0.059 \\
\hline fraction above mean of informal credit in 2002 & 0.059 & 0.061 \\
\hline
\end{tabular}

Table 16: 
Municipalities characteristics by presence of Banco Azteca

Variable from 02 \begin{tabular}{rrrr}
\hline \hline \\
from 02
\end{tabular} after 02 $\begin{array}{r}\text { after 02 no Azteca's } \\
\text { to } 05 \text { before 05 }\end{array}$

DATA

Population size

$\begin{array}{lrrrr}\text { p10 } & 57,375 & 62,773 & 47,106 & 4,318 \\ \text { p25 } & 78,512 & 62,773 & 50,168 & 10,644 \\ \text { p50 } & 227,026 & 63,319 & 57,602 & 19,447 \\ \text { p75 } & 516,255 & 63,864 & 366,068 & 41,402 \\ \text { p90 } & 1,110,997 & 63,864 & 670,162 & 69,381\end{array}$

Percapita Income

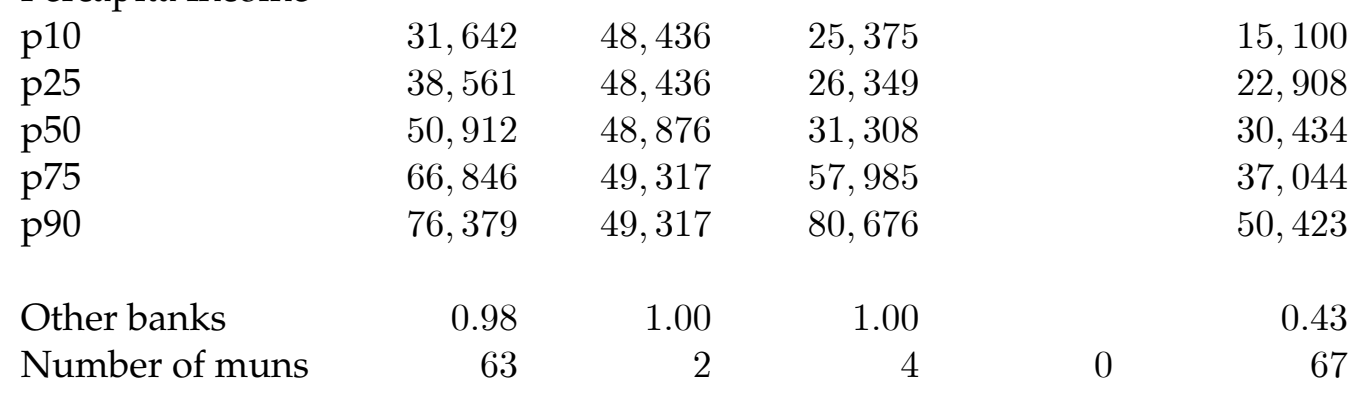

\section{MODEL}

Population size

$\begin{array}{lrrrrr}\text { p10 } & 83,537 & 2,306 & 46,053 & 34,088 & 4,318 \\ \text { p25 } & 137,282 & 24,447 & 55,560 & 37,418 & 9,862 \\ \text { p50 } & 272,307 & 50,262 & 69,449 & 43,827 & 14,952 \\ \text { p75 } & 549,018 & 57,375 & 208,871 & 45,272 & 23,984 \\ \text { p90 } & 1,001,021 & 75,059 & 1,110,997 & 47,106 & 39,308\end{array}$

Percapita Income

$\begin{array}{lrrrrr}\text { p10 } & 30,486 & 34,981 & 27,886 & 23,987 & 13,762 \\ \text { p25 } & 38,695 & 38,561 & 30,556 & 25,375 & 18,789 \\ \text { p50 } & 54,551 & 43,355 & 36,966 & 32,488 & 29,330 \\ \text { p75 } & 68,009 & 49,662 & 47,912 & 33,353 & 39,024 \\ \text { p90 } & 80,731 & 67,674 & 70,645 & 41,873 & 51,731 \\ & & & & & \\ \text { Other banks } & 1.00 & 0.83 & 0.96 & 0.80 & 0.32 \\ \text { Number of muns } & 48 & 6 & 24 & 5 & 53\end{array}$

Table 17: The two panels compare municipalities characteristics by presence of Azteca between the real data and the model simulations. Variables presented are: percentiles of the population distribution of municipalities; percentiles of the Percapita Income distribution; proportion of municipalities with other bank branches; and number of municipalities in each category of Azteca's presence. 
Probability that informal households obtain bank credit

\begin{tabular}{cccc}
\hline \hline & data & model 1 & model 2 \\
\hline azteca & $\begin{array}{c}-0.0108^{* * *} \\
{[0.0032]}\end{array}$ & 0.0000 & 0.0000 \\
& {$[0.0006]$} & {$[0.0003]$} \\
year & $0.0056^{*}$ & 0.0000 & 0.0000 \\
& {$[0.0029]$} & {$[0.0007]$} & {$[0.0003]$} \\
azteca*year & $0.0109^{* *}$ & $0.0716^{* * *}$ & $0.0155^{* * *}$ \\
& {$[0.0048]$} & {$[0.0009]$} & {$[0.0004]$} \\
Constant & -0.0086 & -0.0000 & -0.0000 \\
& {$[0.0088]$} & {$[0.0005]$} & {$[0.0002]$} \\
Observations & 8382 & 464290 & 464290 \\
R-squared & 0.0078 & 0.0500 & 0.0106
\end{tabular}

Table 18: Difference-in-Differefence (DID) regressions. Dependent variable is a dummy equal to one if household borrowed from banks. Column 2 presents the DID regression on the real data. Column 3 presents the DID regression on the simulated data without bounding the continuous distribution of savings. Column 4 presents the DID regression on the simulated data after bounding the continuous distribution of savings with the cut-offs from the real data. 
Probability that informal

hhds obtain loans from pawnshops

\begin{tabular}{cccc}
\hline \hline & data & model 1 & model 2 \\
\hline azteca & $0.0093^{* * *}$ & -0.0005 & -0.0003 \\
& {$[0.0033]$} & {$[0.0005]$} & {$[0.0004]$} \\
year & -0.0022 & $-0.0070^{* * *}$ & $-0.0035^{* * *}$ \\
& {$[0.0028]$} & {$[0.0005]$} & {$[0.0004]$} \\
& & & \\
aztyear & $-0.0114^{* *}$ & $-0.0067^{* * *}$ & $-0.0038^{* * *}$ \\
& {$[0.0050]$} & {$[0.0007]$} & {$[0.0006]$} \\
& & & \\
Constant & $0.0334^{* * *}$ & $0.0185^{* * *}$ & $0.0117^{* * *}$ \\
& {$[0.0090]$} & {$[0.0004]$} & {$[0.0003]$} \\
Observations & 8382 & 464290 & 464290 \\
R-squared & 0.0052 & 0.0030 & 0.0012 \\
& & & \\
\hline
\end{tabular}

Table 19: Difference-in-Differefence (DID) regressions. Dependent variable is a dummy equal to one if household borrowed from pawn shops. Column 2 presents the DID regression on the real data. Column 3 presents the DID regression on the simulated data without bounding the continuous distribution of savings. Column 4 presents the DID regression on the simulated data after bounding the continuous distribution of savings with the cut-offs from the real data. 


\begin{tabular}{ccc}
\multicolumn{3}{c}{$\begin{array}{c}\text { Probability that informal } \\
\text { households save }\end{array}$} \\
\hline \hline & data & model \\
\hline azteca & -0.0892 & $0.0778^{* * *}$ \\
& {$[0.1819]$} & {$[0.0017]$} \\
year & $-0.0590^{* * *}$ & $0.0471^{* * *}$ \\
& {$[0.0133]$} & {$[0.0019]$} \\
aztyear & $-0.0311^{*}$ & $-0.1252^{* * *}$ \\
& {$[0.0185]$} & {$[0.0024]$} \\
Constant & 0.078 & $0.7800^{* * *}$ \\
& {$[0.1999]$} & {$[0.0013]$} \\
& & \\
Observations & 8382 & 464290 \\
R-squared & 0.0239 & 0.0080 \\
& & \\
\hline
\end{tabular}

Table 20: Difference-in-Differefence (DID) regressions. Dependent variable is a dummy equal to one if household saved. Column 2 presents the DID regression on the real data. Column 3 presents the DID regression on the simulated data without bounding the continuous distribution of savings. Column 4 presents the DID regression on the simulated data after bounding the continuous distribution of savings with the cut-offs from the real data. 
Probability that informal households use credit from pawnshops (using different control groups)

\begin{tabular}{ccc}
\hline \hline & & \\
& control 1 & control 2 \\
\hline azteca & -0.0005 & -0.0000 \\
& {$[0.0005]$} & {$[0.0004]$} \\
year & $-0.0070^{* * *}$ & $-0.0084^{* * *}$ \\
& {$[0.0005]$} & {$[0.0004]$} \\
azteca* year & $-0.0067^{* * *}$ & $-0.0052^{* * *}$ \\
& {$[0.0007]$} & {$[0.0006]$} \\
& & \\
constant & $0.0185^{* * *}$ & $0.0179^{* * *}$ \\
& {$[0.0004]$} & {$[0.0003]$} \\
& & \\
obs & 464290 & 582757 \\
R2 & 0.0030 & 0.0028 \\
& & \\
\hline
\end{tabular}

Table 21: Difference-in-Differefence (DID) regressions. Dependent variable is a dummy equal to one if household borrowed from pawn shops. Column 2 presents the DID regression on the simulated data using as control group municipalities where Azteca did not enter. Column 3 presents the DID regression on the simulated data using as control municipalities chosen by Azteca under the scenario that Azteca never entered. 


\begin{tabular}{ccc}
\multicolumn{3}{c}{$\begin{array}{c}\text { Probability that informal } \\
\text { households save }\end{array}$} \\
(using different control groups) \\
\hline \hline & control 1 & control 2 \\
\hline & $0.0778^{* * *}$ & 0.0000 \\
azteca & {$[0.0017]$} & {$[0.0014]$} \\
& & \\
year & $0.0471^{* * *}$ & $-0.0096^{* * *}$ \\
& {$[0.0019]$} & {$[0.0014]$} \\
& & \\
azteca*year & $-0.1252^{* * *}$ & $-0.0685^{* * *}$ \\
& {$[0.0024]$} & {$[0.0019]$} \\
& & \\
constant & $0.7800^{* * *}$ & $0.8578^{* * *}$ \\
& {$[0.0013]$} & {$[0.0010]$} \\
& & \\
obs & 464290 & 582757 \\
R2 & 0.0080 & 0.0078 \\
& & \\
\hline
\end{tabular}

Table 22: Difference-in-Differefence (DID) regressions. Dependent variable is a dummy equal to one if household saved. Column 2 presents the DID regression on the simulated data using as control group municipalities where Azteca did not enter. Column 3 presents the DID regression on the simulated data using as control municipalities chosen by Azteca under the scenario that Azteca never entered. 


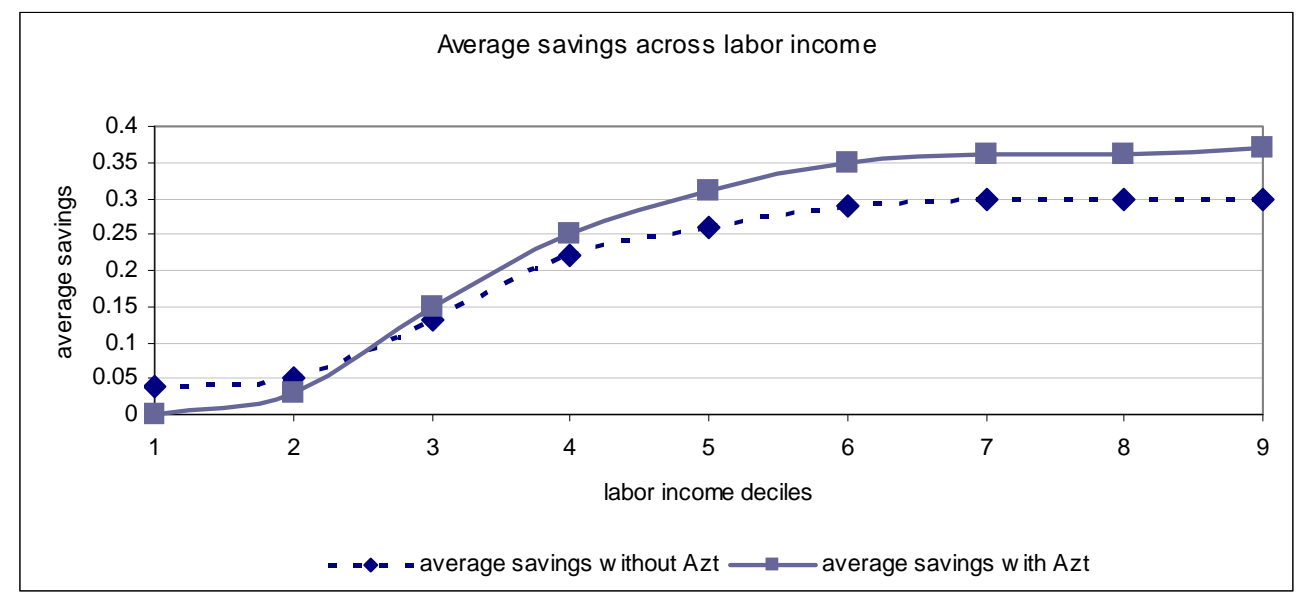

Figure 1: Average savings across labor income deciles from the simulated model with and without Banco Azteca.

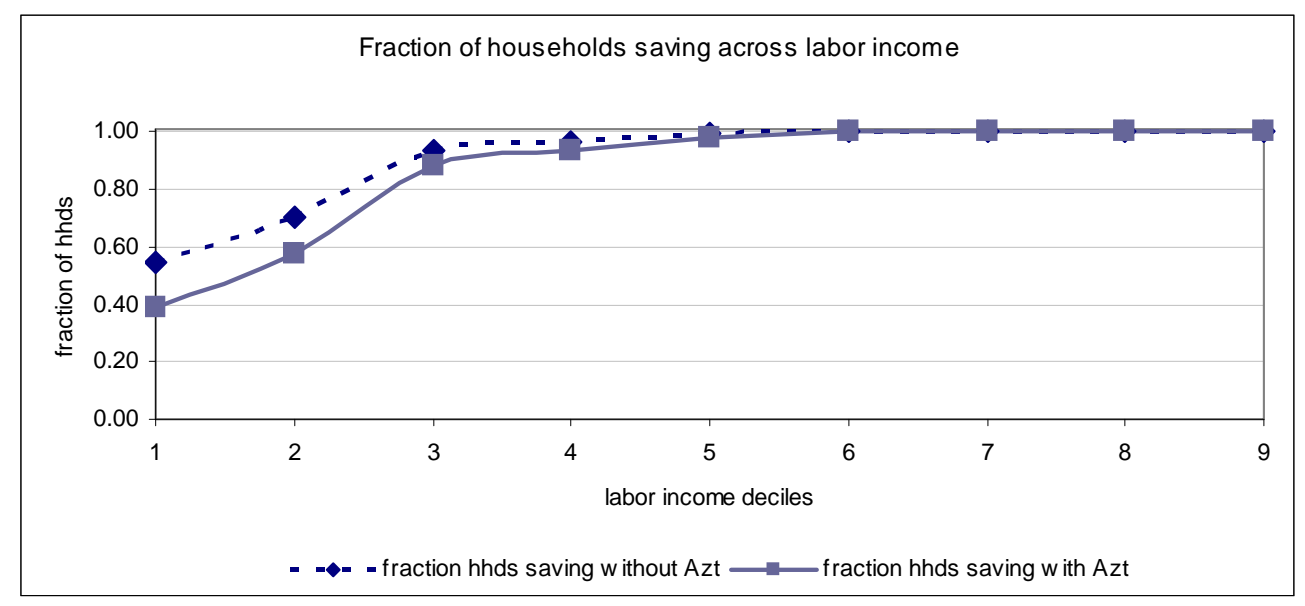

Figure 2: Fraction of households saving across labor income deciles from the simulated model with and without Banco Azteca. 


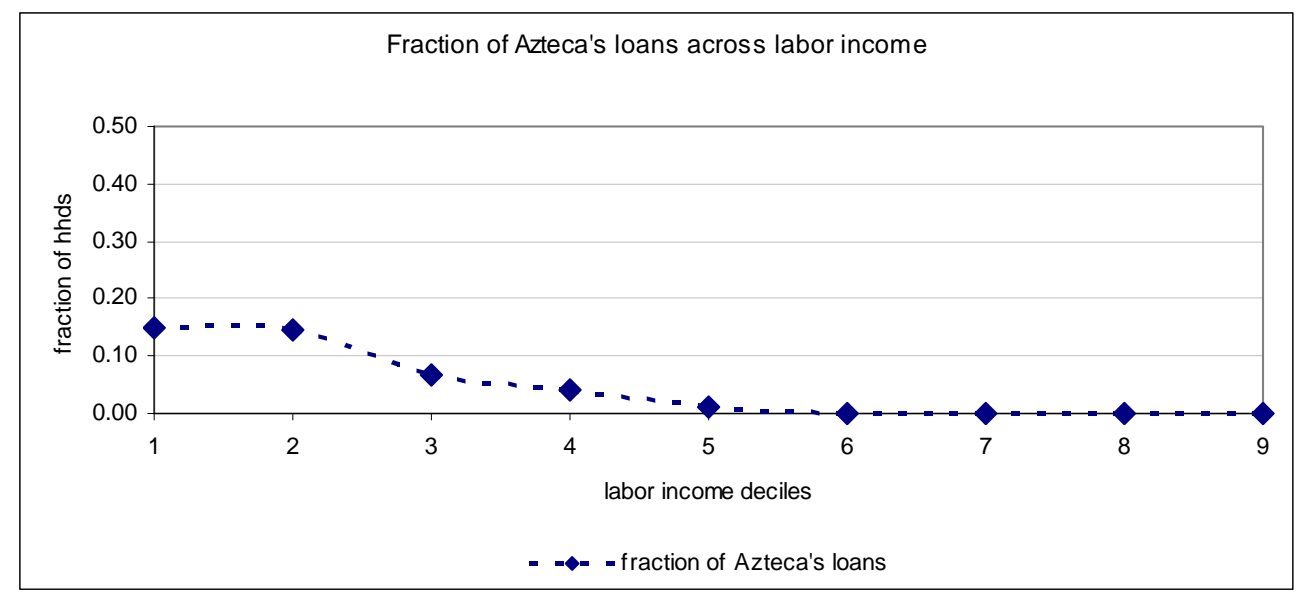

Figure 3: Fraction of households borrowing from Azteca across labor income deciles from the simulated model in municipalities where Banco Azteca located its branches.

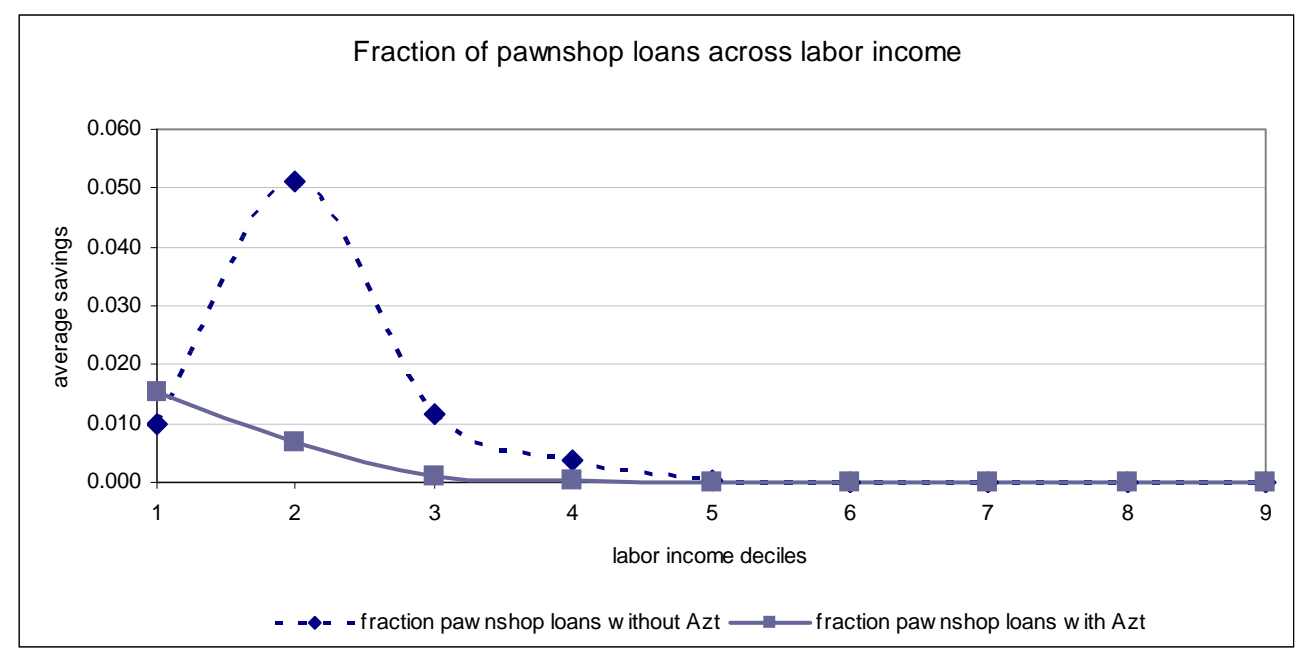

Figure 4: Fraction of households borrowing from pawnshops across labor income deciles from the simulated model in municipalities where Banco Azteca located its branches. 


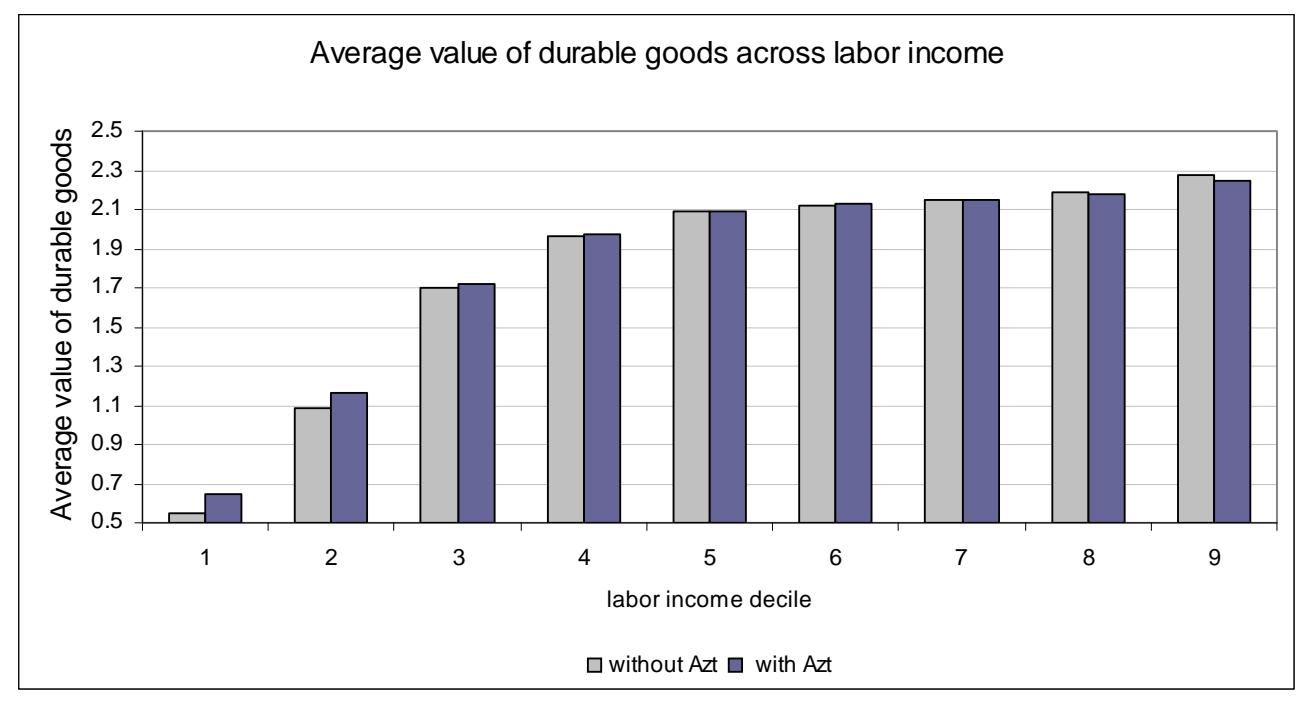

Figure 5: Average value of durable goods across labor income deciles from the simulated model with and without Banco Azteca.

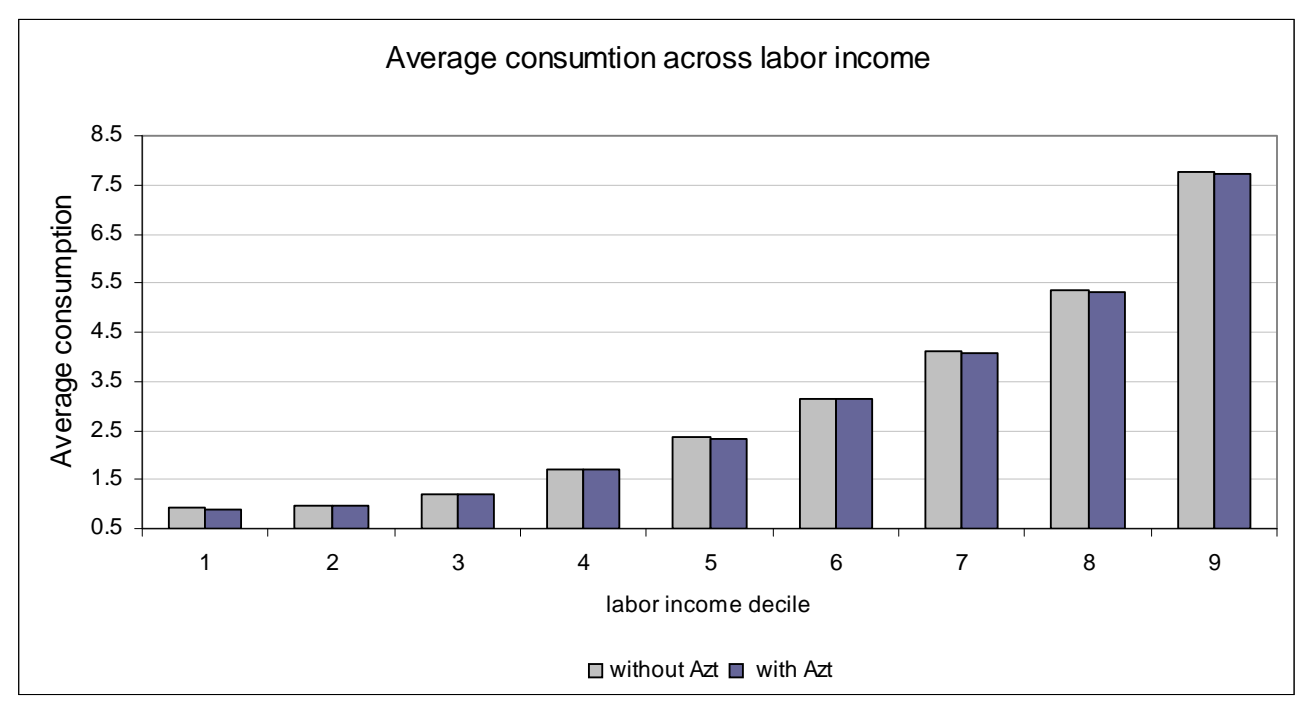

Figure 6: Average consumption of nondurable goods across labor income deciles from the simulated model with and without Banco Azteca. 


\begin{tabular}{ccc}
\multicolumn{3}{c}{ Consumption Smoothing Index } \\
\hline \hline no Azteca & Azteca & Diff \\
\hline \multirow{2}{*}{0.168} & 0.190 & $\begin{array}{c}0.022 \\
(0.0003)\end{array}$
\end{tabular}

Table 23: Mean consumption smoothing index from the simulated data with and without Banco Azteca. This index takes values from 0 to 1 . If index $=1$, households are perfectly smoothing their consumption over time. If index $=0$, the variance in households' consumption equals the variance of households' income.

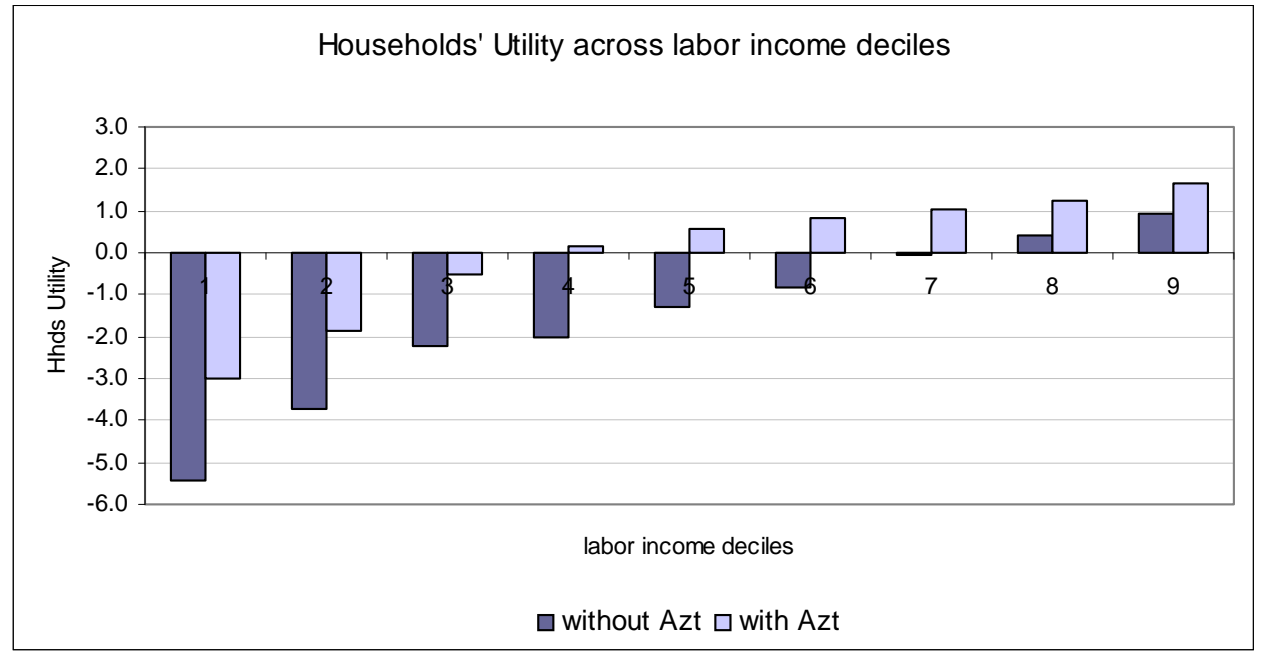

Figure 7: Average welfare across labor income deciles from the simulated data with and without Banco Azteca. 


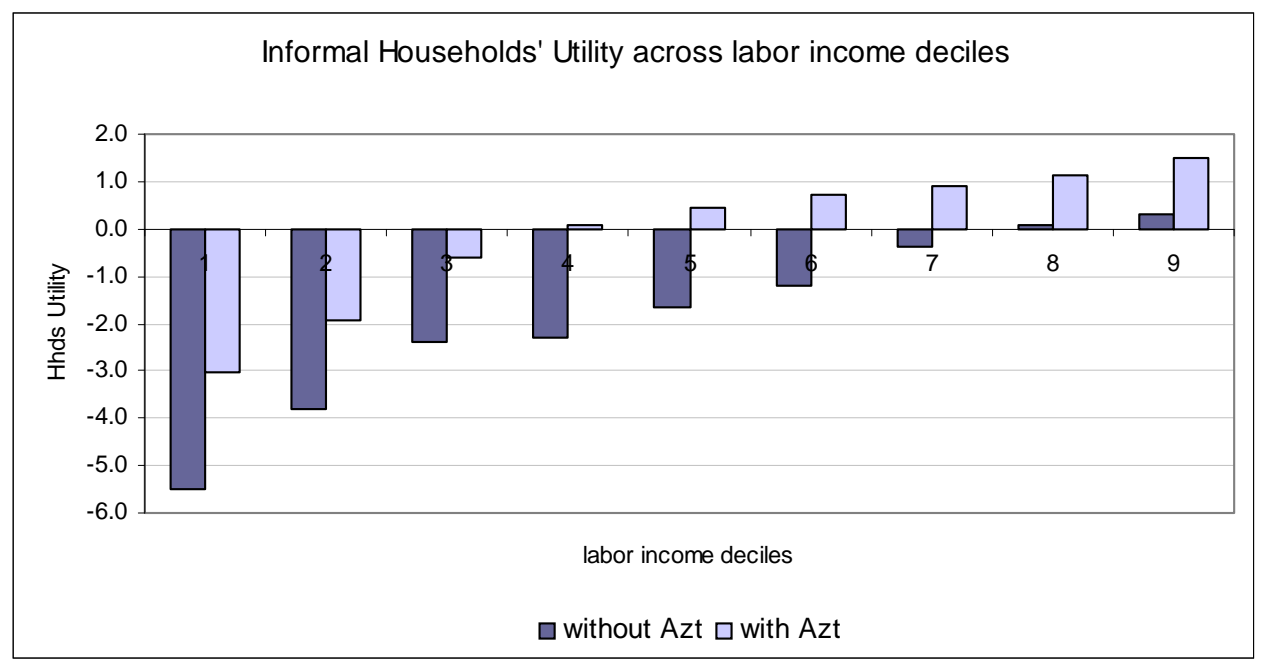

Figure 8: Average welfare of informal households across labor income deciles from the simulated data with and without Banco Azteca.

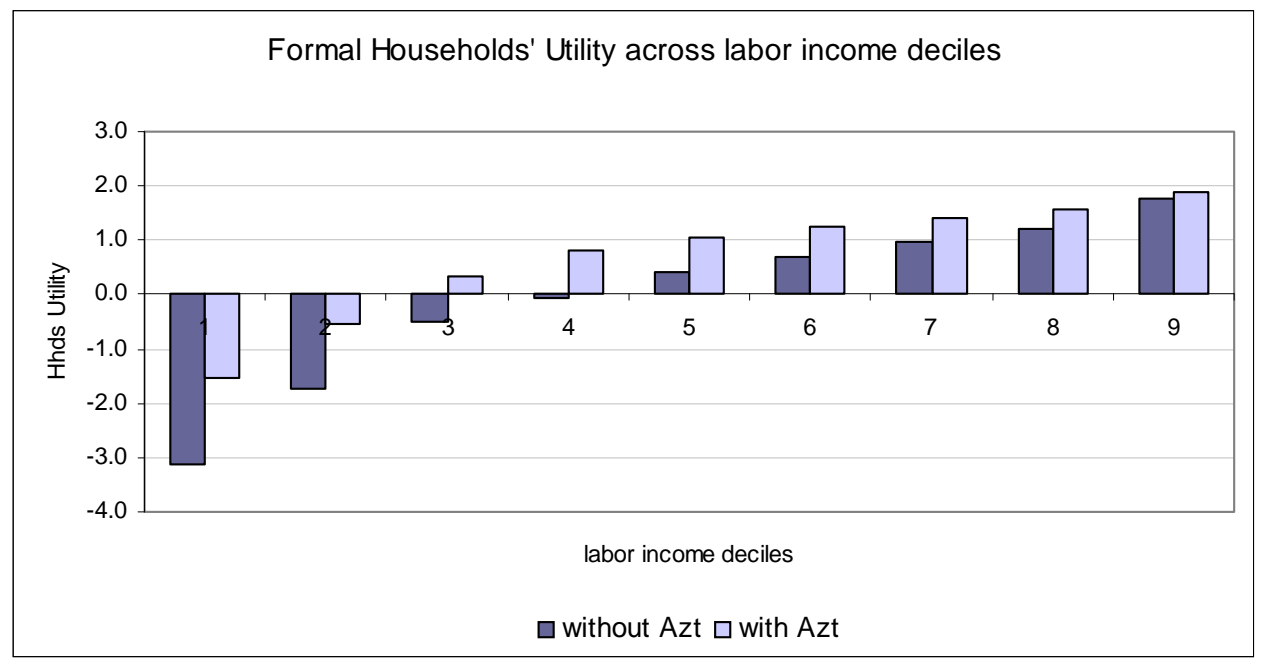

Figure 9: Average welfare of formal households across labor income deciles from the simulated data with and without Banco Azteca. 


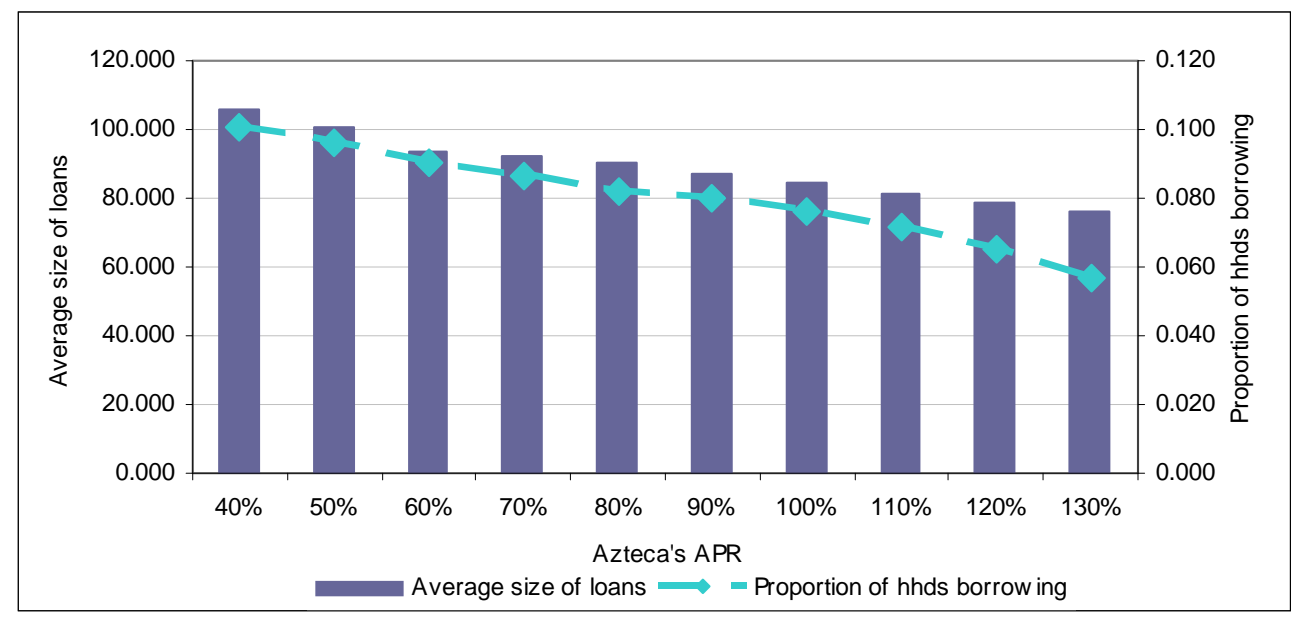

Figure 10: Left axis presents the average size of loans of households borrowing from Azteca at different APRs. Right axis presents the proportion of households borrowing from Azteca at different APRs.

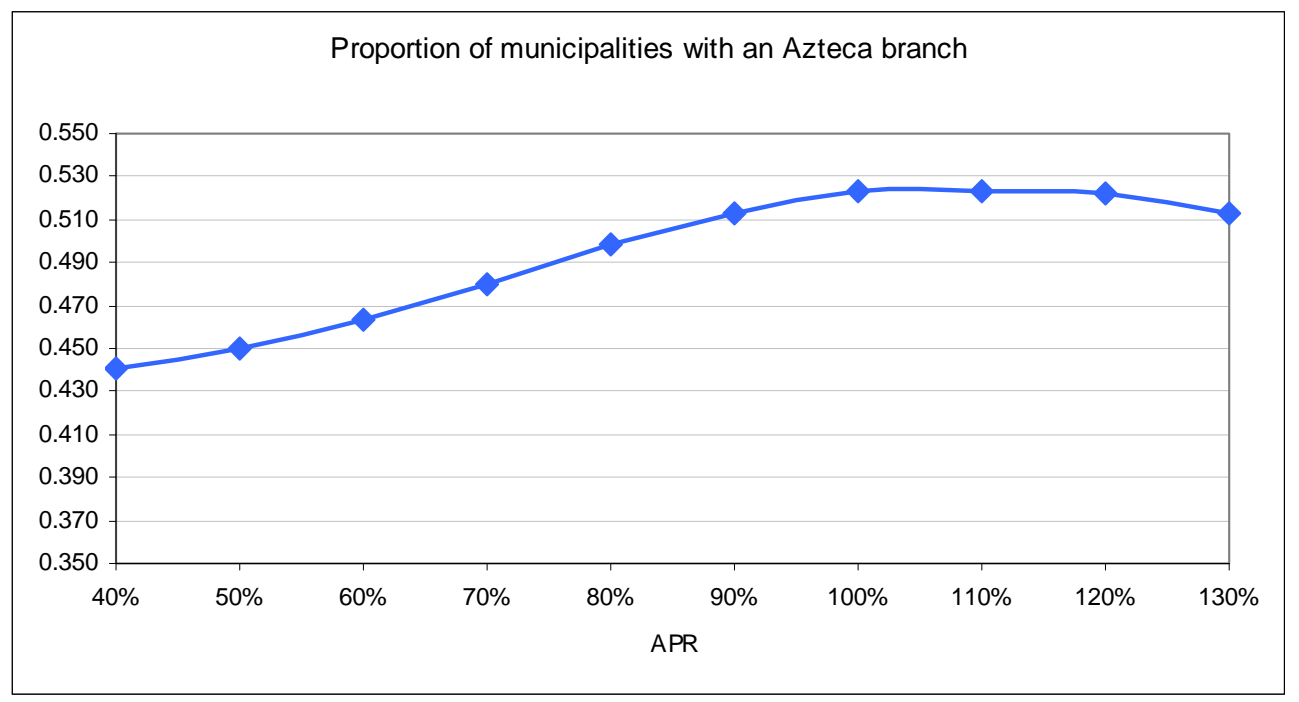

Figure 11: Average welfare across labor income deciles from the simulated data with and without Banco Azteca. 


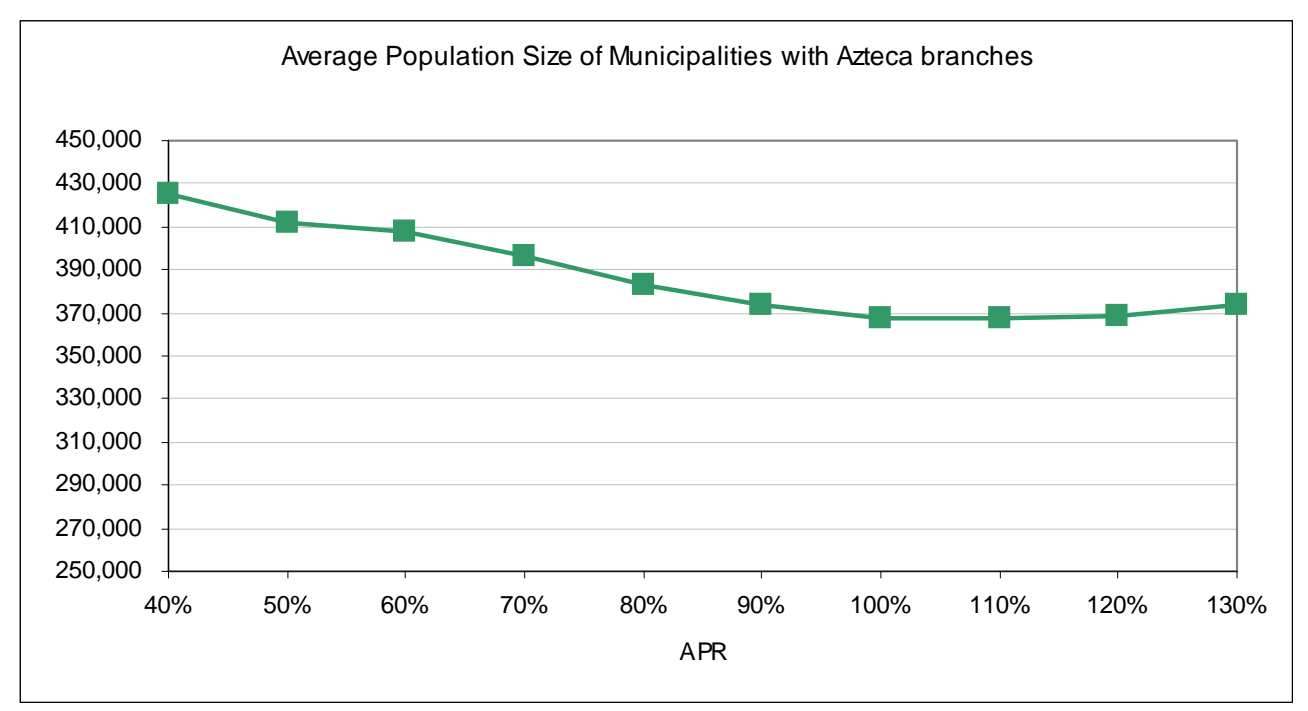

Figure 12: Average population size of municipalities where Azteca locates its branches at different APRs.

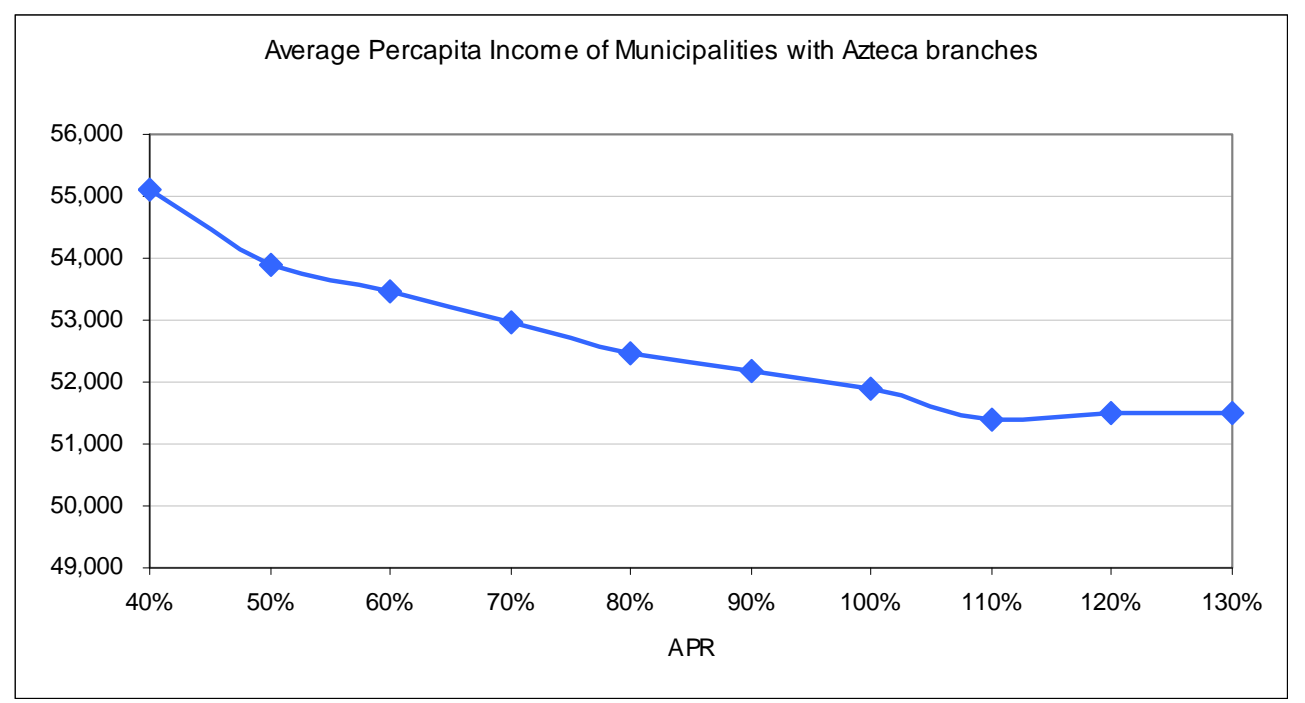

Figure 13: Average percapita income of municipalities where Azteca locates its branches at different APRs. 